\title{
Temper Brittleness of Boron-Treated Steels
}

\author{
Samuel J. Rosenberg
}

\begin{abstract}
Two series of steels, melted to the base composition of 8140 , were studied to ascertain whether titanium and zirconium (present in many commercial boron addition agents) had any adverse effect upon the impact properties of the base steels, particularly with reference to temper brittleness.

The results obtained indicate that with fully hardened steels tempered at $1,200^{\circ} \mathrm{F}$, the presence of relatively small amounts of titanium as introduced into the test steels by the boron addition agents is sufficient to cause an impairment in the Charpy $V$-notch impact properties of the steels or an increased susceptibility to temper brittleness, or both. This was confirmed by the addition of titanium without boron. Similar effects, previously thought possibly due to the presence of zirconium, were not observed.
\end{abstract}

\section{Introduction}

A study of the impact properties of boron-treated steels, conducted at the National Bureau of Standards, ${ }^{1}$ indicated that boron itself had no effect upon the phenomenon of temper brittleness. The increased susceptibility to temper brittleness of some of the boron-treated steels was ascribed to other elements present in the steels in small quantities (from the addition agents) and, by the process of elimination, it appeared that titanium and zirconium. may have been responsible for the effects observed. The purpose of this study was to establish whether or not these elements are responsible for increasing the susceptibility to temper brittleness of boron-treated steel.

The steels tested previously were from a commercial open-hearth heat of 0.4 percent C, 1.6 percent Mn base composition; the steels melted for the present study were electric- and induction-furnace heats of the 8140 type.

\section{Steels Investigated}

One series of steels was melted at the U. S. Bureau of Mines, Pittsburgh, Pa., in a $500-\mathrm{lb}$ basic electricarc furnace. In order to control variations in base composition, only one heat was used. The melt was deoxidized with aluminum. (2 lb/ton) and then split seven ways. All additions of boron were made in the ladle, and the compositions of the addition agents are given in table 1 . Addition agents $\mathrm{X}, \mathrm{Y}$, and $\mathrm{Z}$ were commercial agents selected so that $\mathrm{X}$ contained neither titanium nor zirconium; Y contained titanium but not zirconium; and $\mathrm{Z}$ contained both titanium and zirconium. The steels were poured in the following order:

$\begin{array}{ll}\text { Steel M731 } & \text { No addition (base). } \\ \text { M732 } & \text { FeB. } \\ \text { M733 } & \text { Addition agent X. } \\ \text { M734 } & \text { FeB plus FeTi. } \\ \text { M735 } & \text { Addition agent Y. } \\ \text { M736 } & \text { Addition agent Z. } \\ \text { M737 } & \text { FeB plus FeZr. }\end{array}$

${ }_{1}$ Samuel J. Rosenberg and John D. Grimsley, A study of the impact properties of boron-treated steels, J. Iron Steel Inst. 182, 278 (March 1956).
TABLE 1. Composition of the addition agents

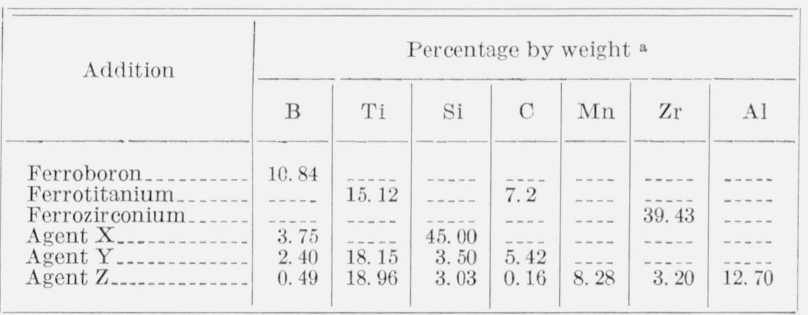

a Analyses were made only for the elements indicated.

All steels were poured into split steel molds, $2 \frac{3 / 4}{4}$ in. square at the bottom, $3 \frac{3}{4}$ in. square at the top, and 15 in. tall, equipped with hot tops. After discarding the hot tops, the yield was about $35 \mathrm{lb}$ of usable metal.

A second series of 8140 steels was melted in an induction furnace at NBS. This also was a split heat deoxidized with aluminum ( $2 \mathrm{lb} / \mathrm{ton})$, and, as before, the additions noted were made in the ladle. The order of pouring was as follows:

$\begin{array}{ll}\text { Steel M744 } & \text { No addition (base). } \\ \text { M745 } & \text { FeTi. } \\ \text { M746 } & \text { FeZr. } \\ \text { M747 } & \text { FeB. } \\ \text { M748 } & \text { FeB plus FeTi. }\end{array}$

The sixth steel, designed to have an addition of FeB plus FeZr, unfortunately was lost. Analyses of the two series of steels are given in table 2 . It will be noted that the boron contents of the Bureau of Mines steels were higher than those normally obtained in boron-treated steels; those of the NBS steels were within the normal range.

The ingots were cleaned by shot-blasting or grinding, forged to $2 \frac{1}{2} \mathrm{in}$. square, and then rolled to $1 \frac{114}{4}$-in.thick plate. A 5-in. length was sheared from the bottom of the slabs for Jominy specimens, and the remainder of the slabs were rolled to $\frac{5}{8}$-in.-thick plate. Hot-working was started at $2,150^{\circ}$ to $2,200^{\circ}$ $\mathrm{F}$ and continued to $1,600^{\circ}$ to $1,700^{\circ} \mathrm{F}$; each slab was reheated once during fabrication. The hotrolled plates were cut into lengths of $14 \mathrm{in}$. prior to 
TAвLE 2. Compositions of the test steels

\begin{tabular}{|c|c|c|c|c|c|c|c|c|c|c|c|c|c|}
\hline \multirow{2}{*}{ Steel } & \multirow{2}{*}{ Addition } & \multicolumn{12}{|c|}{ Percentage by weighta } \\
\hline & & $\mathrm{C}$ & Mn & $P$ & s & $\mathrm{Si}$ & $\mathrm{Ni}$ & $\mathrm{Cr}$ & Mo & $\mathrm{Ti}$ & $\mathrm{Zr}$ & B & $\mathrm{N}$ \\
\hline $\begin{array}{l}\text { M731 } \\
\text { M732 } \\
\text { M733 } \\
\text { M734 } \\
\text { M735 } \\
\text { M736 } \\
\text { M737 }\end{array}$ & $\begin{array}{l}\text { None } \\
\text { FeB } \\
\text { Agent X } \\
\text { FeB + FeTi } \\
\text { Agent Y } \\
\text { Agent Z } \\
\text { FeB + FeZr }\end{array}$ & \begin{tabular}{c}
0.43 \\
\hdashline... \\
\\
\hdashline .43
\end{tabular} & $\begin{array}{c}0.85 \\
-1 . \\
-91 \\
.9 \\
.91\end{array}$ & \begin{tabular}{c}
0.022 \\
$-\cdots$ \\
\hdashline$-\cdots$ \\
-028 \\
-0
\end{tabular} & \begin{tabular}{c}
0.018 \\
\hdashline .18 \\
\hdashline .014
\end{tabular} & $\begin{array}{c}0.22 \\
-\cdots . . \\
-.- \\
-. . \\
.25\end{array}$ & $\begin{array}{c}0.30 \\
\cdots . . . \\
-31\end{array}$ & \begin{tabular}{c}
0.52 \\
$\cdots$ \\
\\
\hdashline .50
\end{tabular} & $\begin{array}{c}0.12 \\
-. . \\
.12\end{array}$ & $\begin{array}{l}\text { (b) } \\
\text { (b) } \\
\text { (b) } \\
0.015 \\
.016 \\
.033 \\
\text { (b) }\end{array}$ & $\begin{array}{l}\text { (b) } \\
\text { (b) } \\
\text { (b) } \\
\text { (b) } \\
\text { (b) } \\
0.004 \\
<.005\end{array}$ & $\begin{array}{l}\text { (b) } \\
0.0035 \\
.0025 \\
.0036 \\
.0047 \\
.0024 \\
.0038\end{array}$ & $\begin{array}{l}0.006 \\
.005 \\
.005 \\
.006 \\
.007 \\
.007 \\
.006\end{array}$ \\
\hline $\begin{array}{l}\text { M744 } \\
\text { M745 } \\
\text { M746 } \\
\text { M747 } \\
\text { M748 }\end{array}$ & $\begin{array}{l}\text { None } \\
\text { FeTi } \\
\text { FeZrr } \\
\text { FeB } \\
\text { FeB+FeTi }\end{array}$ & $\begin{array}{l}.40 \\
.39 \\
.39 \\
.39 \\
.38\end{array}$ & \begin{tabular}{c}
.77 \\
-.83 \\
\hdashline .83
\end{tabular} & $\begin{array}{c}.010 \\
-\cdots \\
-\cdots- \\
-\cdots\end{array}$ & $\begin{array}{l}.012 \\
--\cdots \\
-\cdots- \\
-\cdots-\end{array}$ & $\begin{array}{c}.32 \\
-. .- \\
-.-1 \\
.32\end{array}$ & \begin{tabular}{c}
.31 \\
\hdashline .30 \\
..-- \\
.30
\end{tabular} & \begin{tabular}{c}
.49 \\
\hdashline .49 \\
\hdashline .49
\end{tabular} & \begin{tabular}{c}
.11 \\
\hdashline .11 \\
-11
\end{tabular} & $\begin{array}{l}\text { (b) } \\
.025 \\
\text { (b) } \\
\text { (b) } \\
.021\end{array}$ & $\begin{array}{l}\text { (b) } \\
\text { (b) } \\
.003 \\
\text { (b) } \\
\text { (b) }\end{array}$ & $\begin{array}{l}\text { (b) } \\
\text { (b) } \\
\text { (b) } \\
.0018 \\
.0016\end{array}$ & $\begin{array}{l}.006 \\
.005 \\
.005 \\
.005 \\
.006\end{array}$ \\
\hline
\end{tabular}

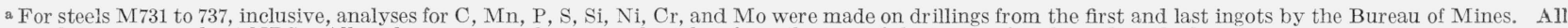
other analyses were made at NBS. All analyses were made on samples taken from the tops of the ingots after discarding the hot tops.

b Not added to these particular steels and presumed not present, hence no analyses were made.

normalizing. The schedule of heat treating and machining operations was as follows:

Normalize $-1 \frac{1}{2}$ hr at $1,650^{\circ} \mathrm{F}$, air-cool.

Rough machine specimens to 2.165 in. long by 0.415 in. square.

Harden-1/2 hr at $1,600^{\circ} \mathrm{F}$, oil-quench.

Temper- 1 hr at $1,200^{\circ} \mathrm{F}$, cool at three different rates: (1) water-quench, (2) air-cool, (3) furnace-cool at $30^{\circ} \mathrm{F} / \mathrm{hr}$.

One group of specimens water-quenched from the tempering temperature was stress-relieved $1 \mathrm{hr}$ at $600^{\circ} \mathrm{F}$; another group of waterquenched specimens was isothermally treated by holding for $48 \mathrm{hr}$ at $930^{\circ} \mathrm{F}$. Some of these treatments were omitted on some of the steels, as indicated in the discussion.

Following heat treatment, all specimens were ground to size (0.394 in. square) and notched (Charpy standard $V$-notch). The hardnesses resulting from these various treatments are given in table 3 .

TABLE 3. Hardness of the Charpy impact specimens after tempering at $1,200^{\circ} \mathrm{F}$

\begin{tabular}{|c|c|c|c|c|c|c|}
\hline \multirow[b]{2}{*}{ Steel } & \multirow[b]{2}{*}{ Addition agent } & \multicolumn{5}{|c|}{ Rockwell $\mathrm{Ca}$, after indicated treatment ${ }^{b}$} \\
\hline & & $\begin{array}{c}\text { Water- } \\
\text { quenched }\end{array}$ & $\begin{array}{l}\text { Water- } \\
\text { quenched } \\
\text { plus } 1 \mathrm{hr} \\
\text { at } 600^{\circ} \mathrm{F}\end{array}$ & $\begin{array}{c}\text { Air- } \\
\text { cooled }\end{array}$ & $\begin{array}{l}\text { Fur- } \\
\text { nace- } \\
\text { cooled }\end{array}$ & $\begin{array}{l}\text { Water- } \\
\text { quenched } \\
\text { plus } 48 \mathrm{hr} \\
\text { at } 930^{\circ} \mathrm{F}\end{array}$ \\
\hline M731 & None_ & 27.1 & 26.1 & 25.7 & 25.7 & 27.4 \\
\hline M732 & & 27.0 & 25.3 & 25.4 & 25.7 & 27.2 \\
\hline M733 & Agent $\mathrm{X}$ & 27.2 & 26.6 & 26. 0 & 26. 2 & 27.7 \\
\hline M734 & $\mathrm{FeB}+\mathrm{FeTi}$ & 27.6 & 27.1 & 26.5 & 26.7 & \\
\hline M735 & Agent Y & 27.5 & 27.0 & 26.4 & 26.5 & 28.0 \\
\hline M736 & Agent $Z_{-}$ & 27.8 & 27.5 & 26.9 & 27.2 & \\
\hline M737 & $\mathrm{FeB}+\mathrm{FeZr}$ & 26.4 & 25.7 & 25.7 & 25.8 & 27.6 \\
\hline & None & & & -.. & 22.6 & \\
\hline M 745 & FeTi & 24.2 & & $\ldots$ & 23.6 & 23.6 \\
\hline M746 & & 23.6 & $\cdots$ & -... & 21.8 & 22.7 \\
\hline M747 & $\mathrm{FeB}$ & 23. & -... & .... & 21.9 & 22.5 \\
\hline M748 & $\mathrm{FeB}+\mathrm{FeTi}$ & 24.8 & ... & ... & 22.9 & 23.7 \\
\hline
\end{tabular}

a Each hardness value represents the average of all determinations made on all of the specimens given the indicated treatment.

These treatments followed the 1 -hr temper at $1,200^{\circ} \mathrm{F}$.

\section{Results and Discussion}

End-quench (Jominy) hardenability tests were made on specimens of all of the steels; the results are shown in figures 1 and 2 . The effectiveness of the

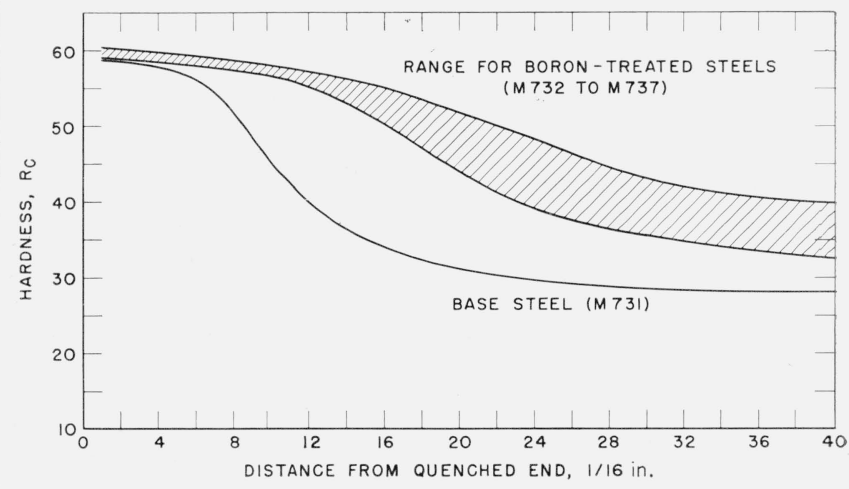

Figure 1. End-quench hardenability curves of the steels melted at the Bureau of Mines.

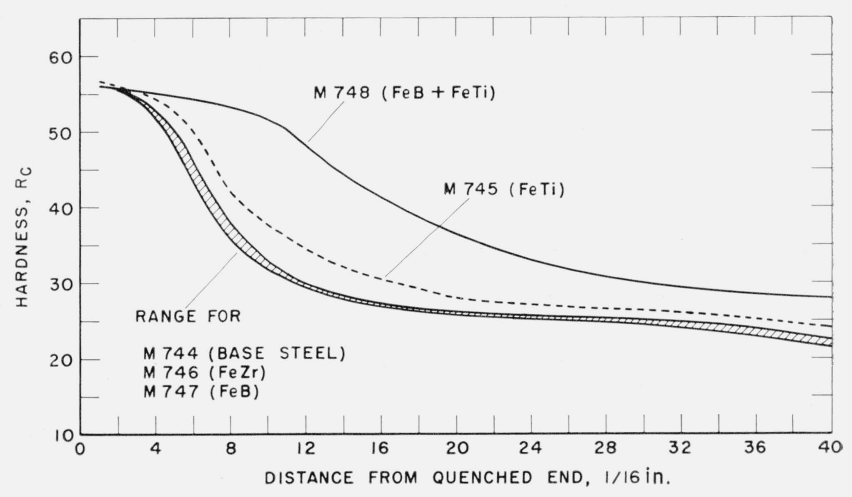

FIGURE 2. End-quench hardenability curves of the steels melted at the National Bureau of Standards.

boron addition in increasing the hardenability of all the boron-treated steels melted at the Bureau of Mines is apparent (fig. 1); the boron-treated steel M747 melted at NBS did not, however, show any increase in hardenability (fig. 2). It has been shown ${ }^{2}$ that only the portion of boron that is in solid solution at the time of quenching contributes toward an increase in hardenability. Boron that is undis. solved or in the form of compounds is ineffective.

2 Thomas G. Digges, Carolyn R. Irish, and Nesbit L. Carwile, Effect of boron on the hardenability of high-purity alloys and commercial steels, J. Research NBS 41, 545 (1948) RP1938. 
Although steel M747 was treated with aluminum, it is possible that all of the nitrogen was not fixed as aluminum nitride and that nitrogen combined with the boron to form a boron nitride. That the boron was not lost from the steel during hot-working was confirmed by a check spectrochemical determination made on the Jominy specimen itself; the value of 0.0017 percent of boron obtained was a close check of the original value of 0.0018 percent (table 2 ).

Charpy impact tests were made over a range of temperatures from ambient to $-320^{\circ} \mathrm{F}$; generally 12 specimens were required for establishing the curve of impact energy versus test temperature. Because of a shortage of material, the curves of some of the isothermally embrittled Bureau of Mines steels were defined by fewer specimens. Usually one specimen was broken at each temperature, although in some cases duplicate specimens were used. All impact tests were made in a machine of 240 -ft-lb capacity; specimens were cooled in suitable liquid baths for at least $30 \mathrm{~min}$ prior to breaking. After fracture, the relative proportion of brittle and fibrous fracture was determined for each specimen. Results of the impact tests are presented graphically in figures 3 to 14 .

Examination of the curves summarizing the data obtained on the Bureau of Mines steels (figs. 3 to 9), using the water-quenched steels as a base, showed that air-cooling from the tempering temperature had a generally minor effect upon the impact properties. A stress relief at $600^{\circ} \mathrm{F}$ after water-quenching from the tempering temperature also had a minor effect upon the impact properties. Furnace-cooling from the tempering temperature had a definite

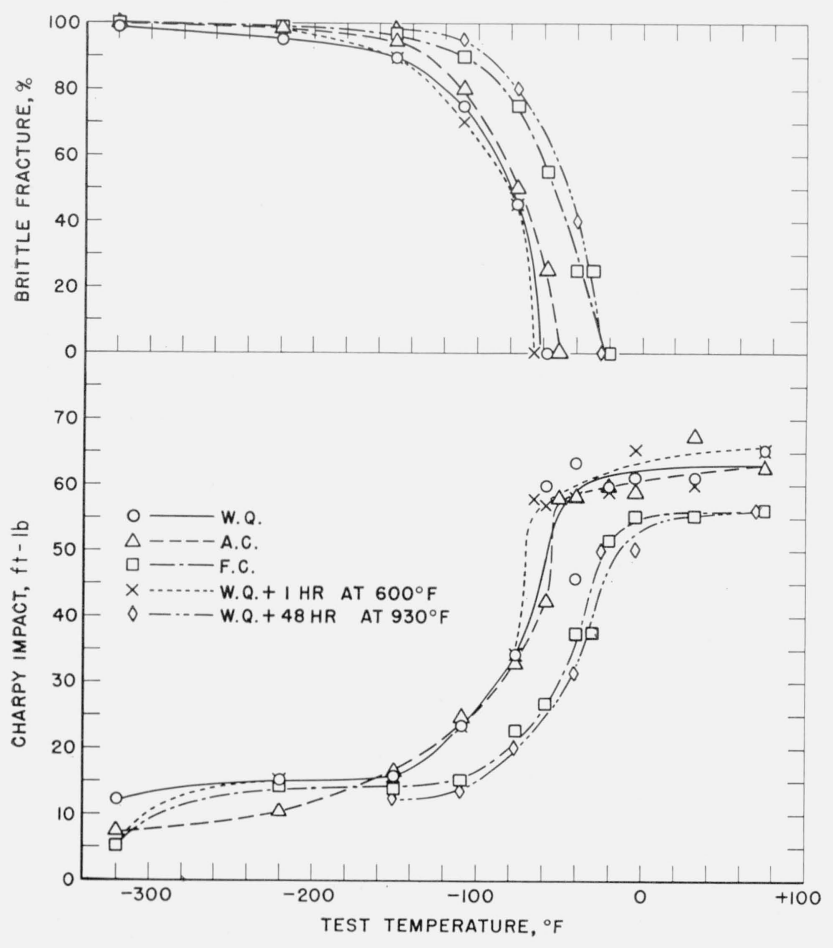

Figure 3. Impact curves for Bureau of Mines steel M731 (base steel).

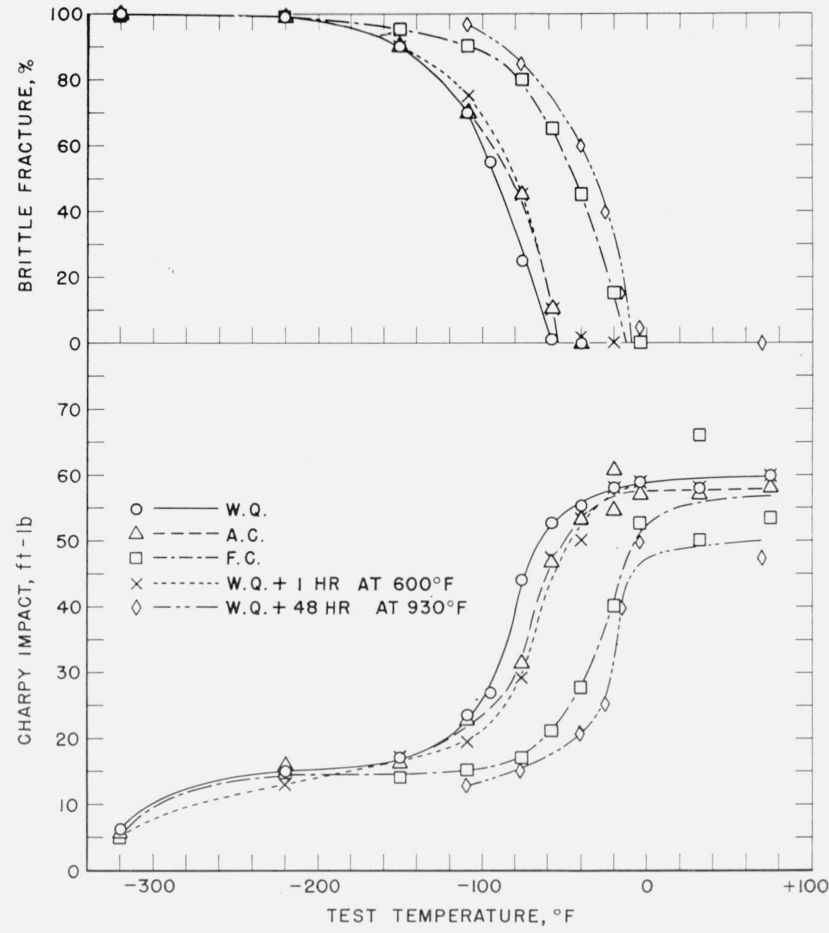

Figure 4. Impact curves for Bureau of Mines steel Mr32 ( $\mathrm{FeB})$.

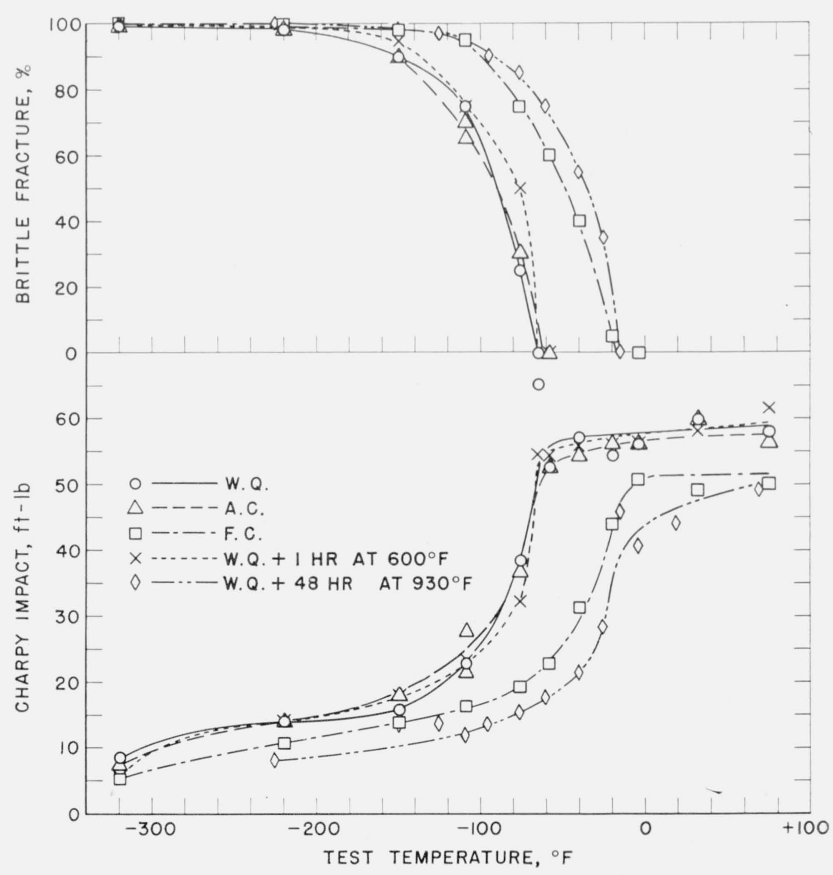

Figure 5. Impact curves for Bureau of Mines steel M733 (agent X).

embrittling effect on all of the steels, as did the 48-hr treatment at $930^{\circ} \mathrm{F}$ following water-quenching from the tempering temperature. This last treatment was not used for steels M734 and M736 because of insufficient material. 


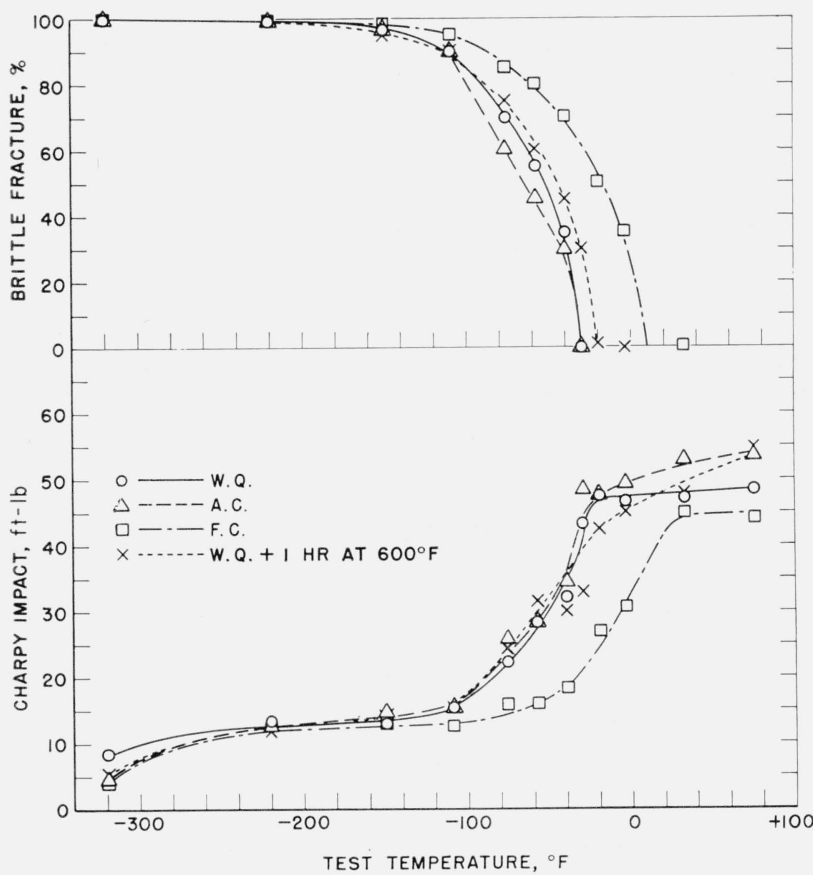

Figure 6. Impact curves for Bureau of Mines steel M734 (FeB plus Fe'Ti).

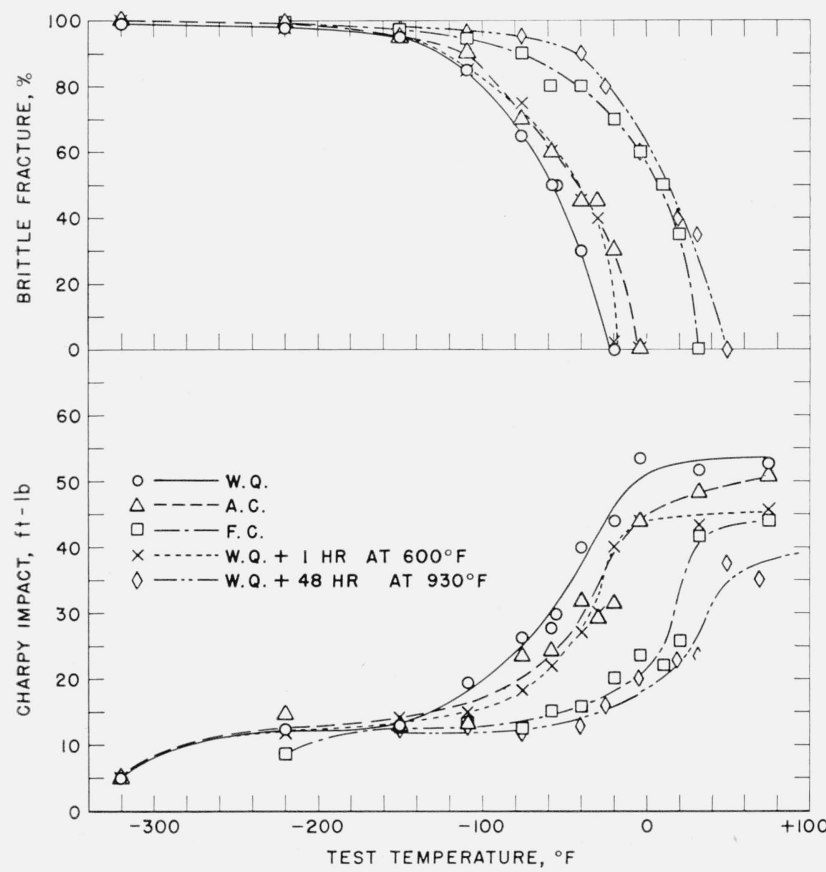

Figure 7. Impact curves for Bureau of Mines steel M735 (agent $Y$ ).

In view of the trends shown by the Bureau of Mines steels, no tests were made on the NBS steels as air-cooled from the tempering temperature, nor as water-quenched followed by the stress-relief treatment. Only steel M747 (FeB, fig. 13) showed no temper embrittlement. Because base steel M744 (fig. 10) showed some temper embrittlement, it would seem as if the addition of boron alone were a curative; that this is not so may be seen by comparing the corresponding Bureau of Mines steels (figs. 3 and 4) and from the results of a previous study (see footnote 1). However, the Bureau of Mines steel M732 contained 0.0035 percent of $B$, and the hardenability was increased over that of the base steel; the

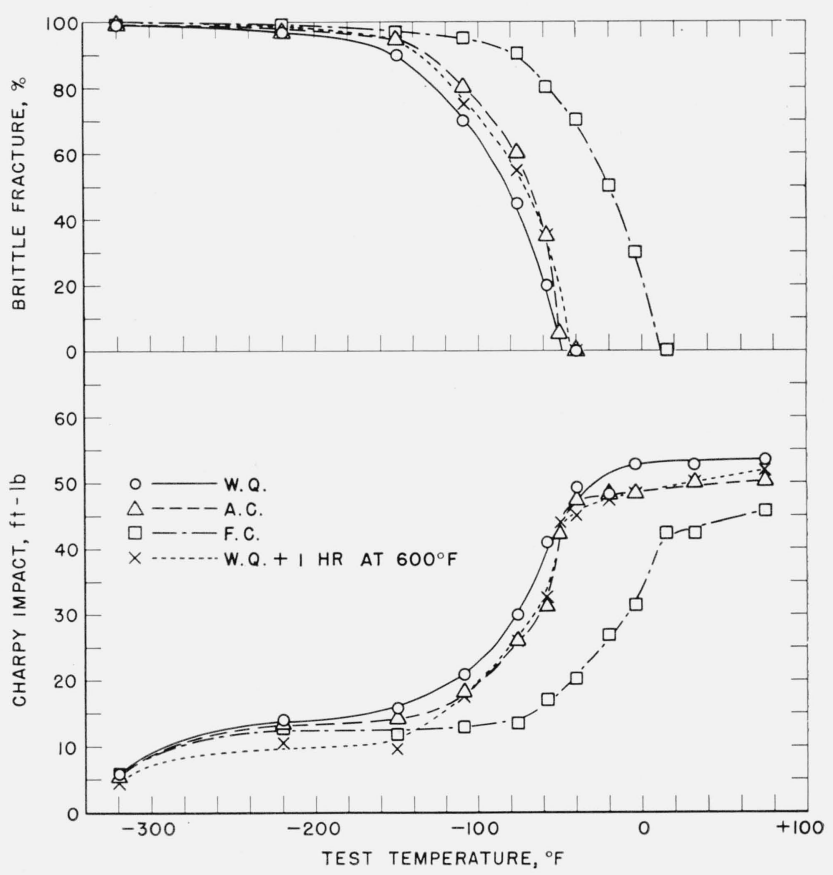

Figure 8. Impact curves for Bureau of Mines steel M736 (agent $Z$ ).

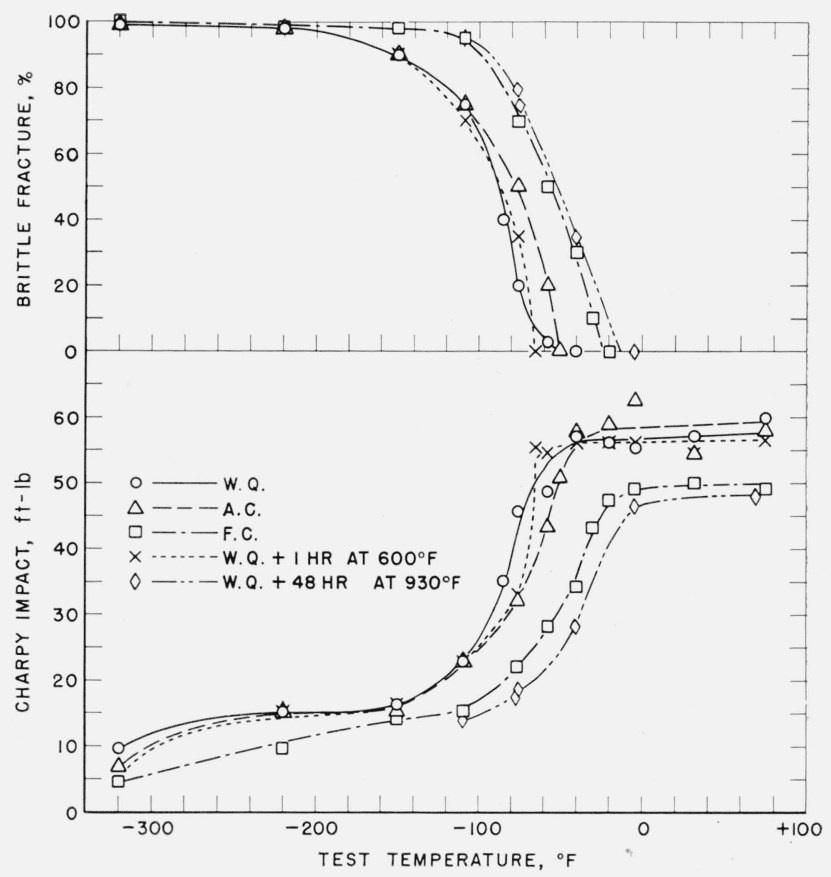

Figure 9. Impact curves for Bureau of Mines steel M737 (FeB plus FeZr). 


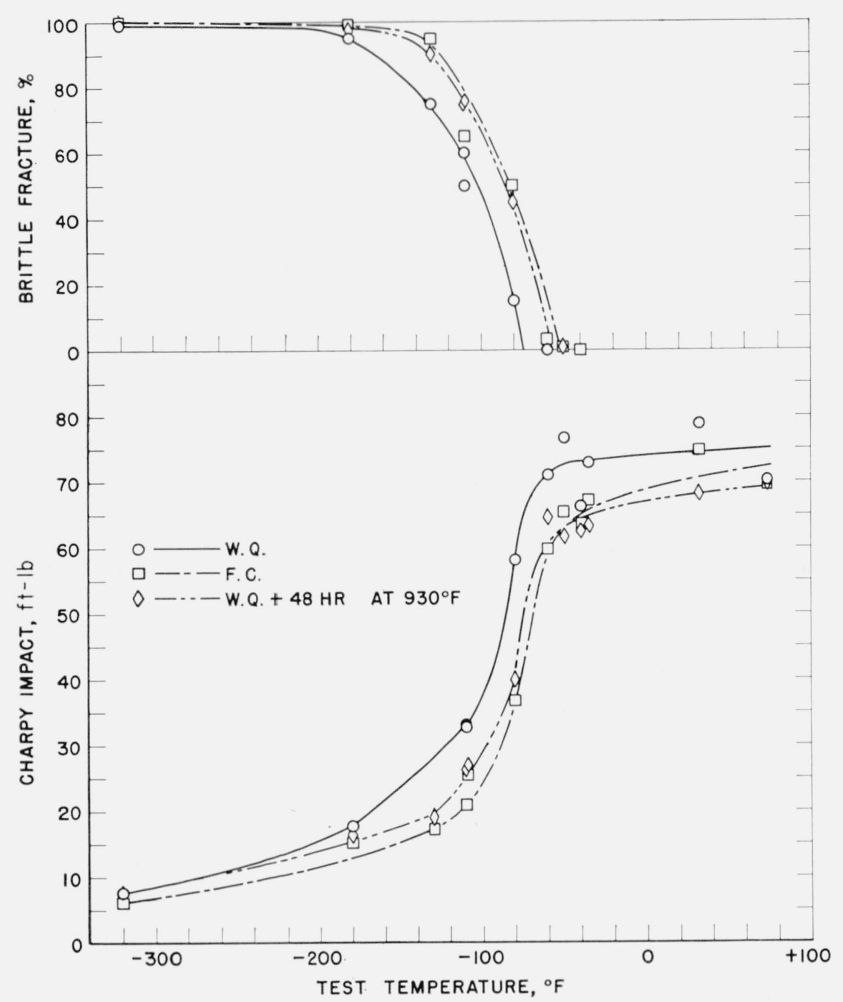

Figure 10. Impact curves for the National Bureau of Standards steel M744 (base).

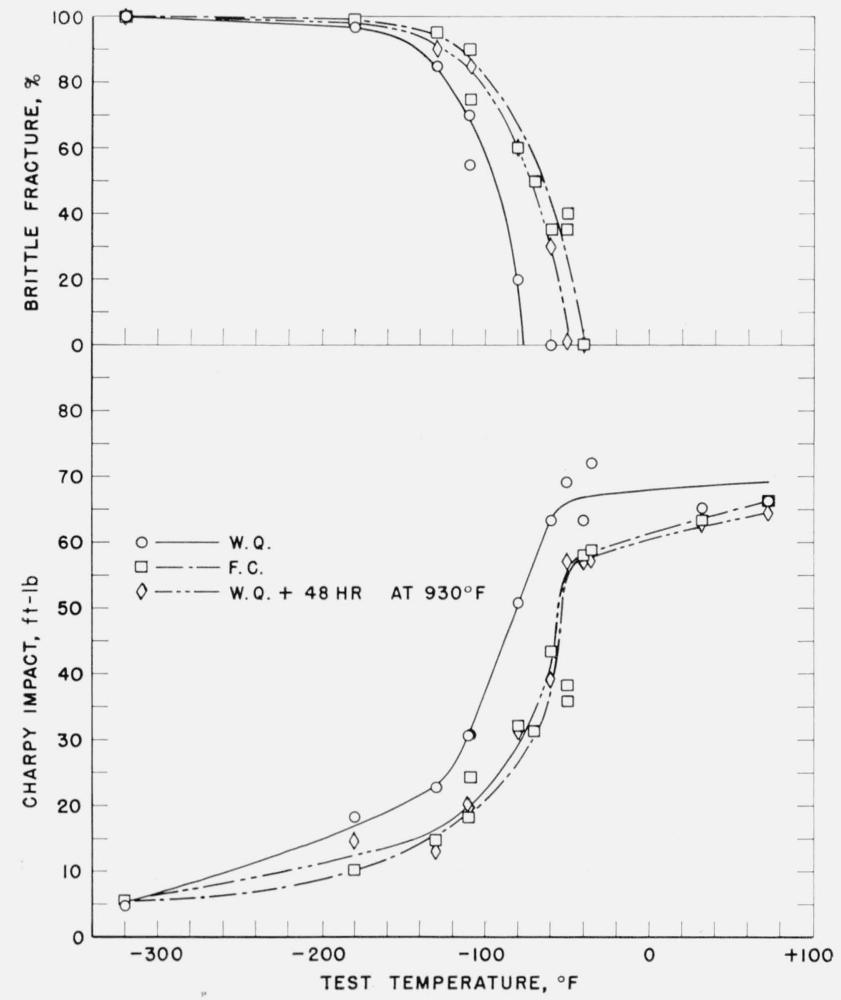

Figure 11. Impact curves for the National Bureau of Standards steel $M^{7} 45$ (FeTi).

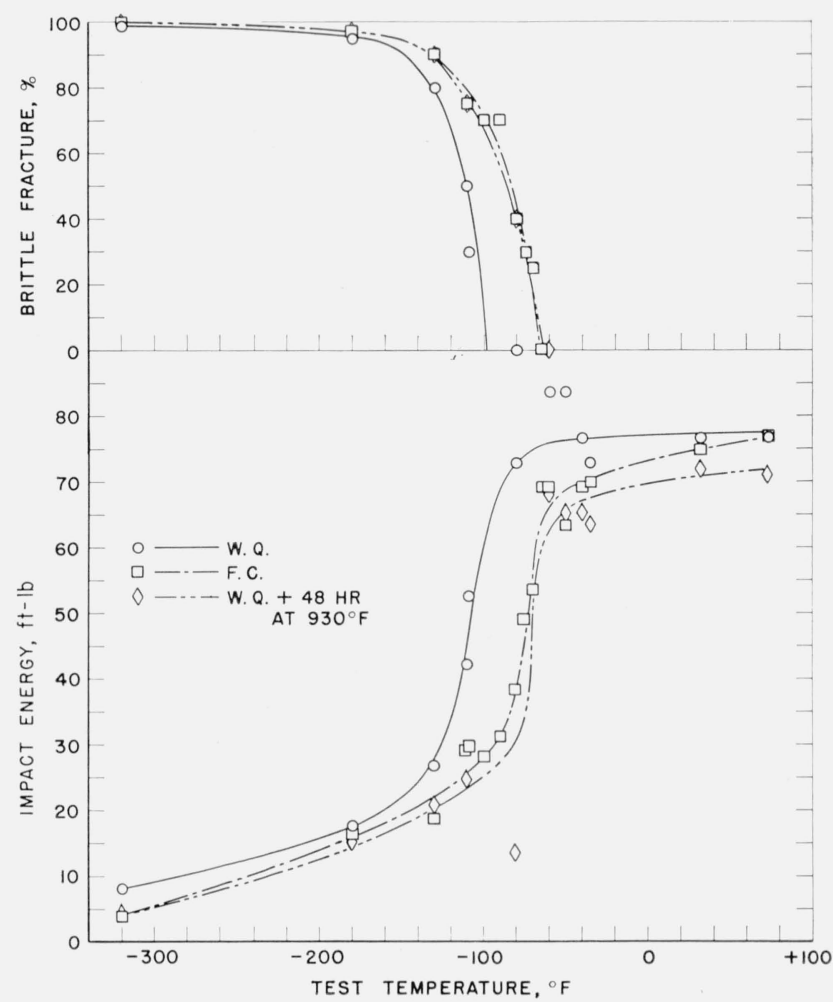

Figure 12. Impact curves for the National Bureau of Standards steel $M 746$ (FeZr).

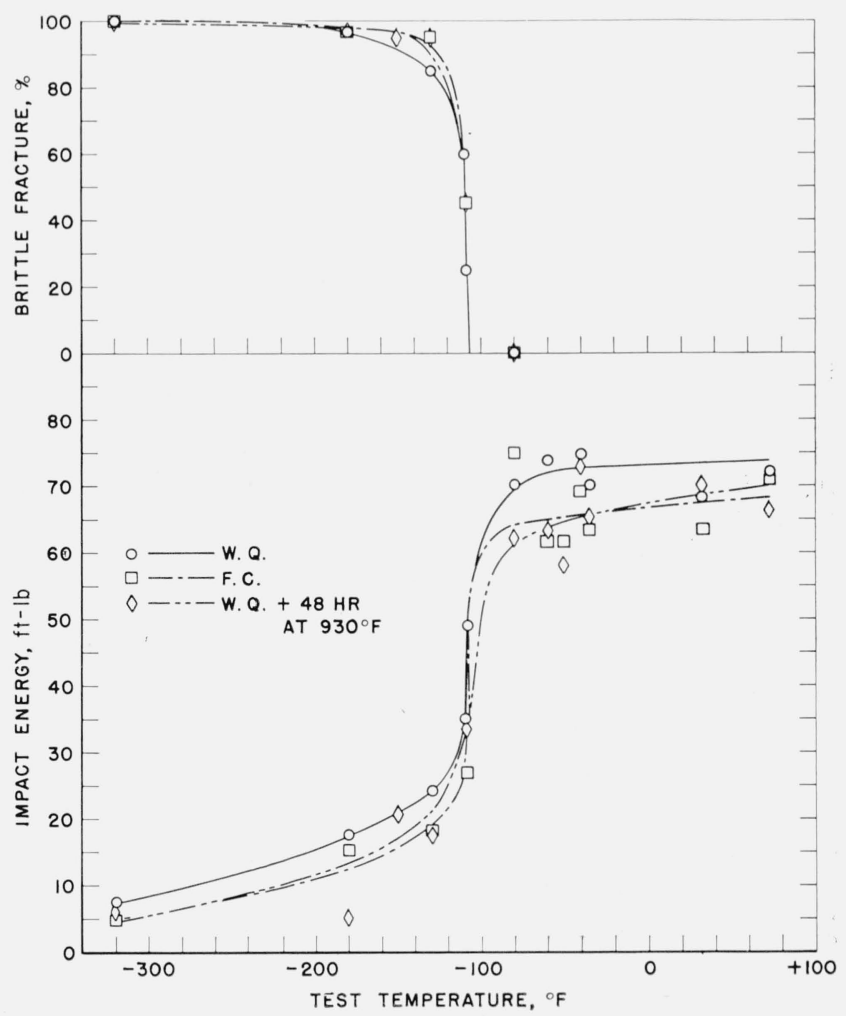

Figure 13. Impact curves for the National Bureau of Standards steel M747 (FeB). 


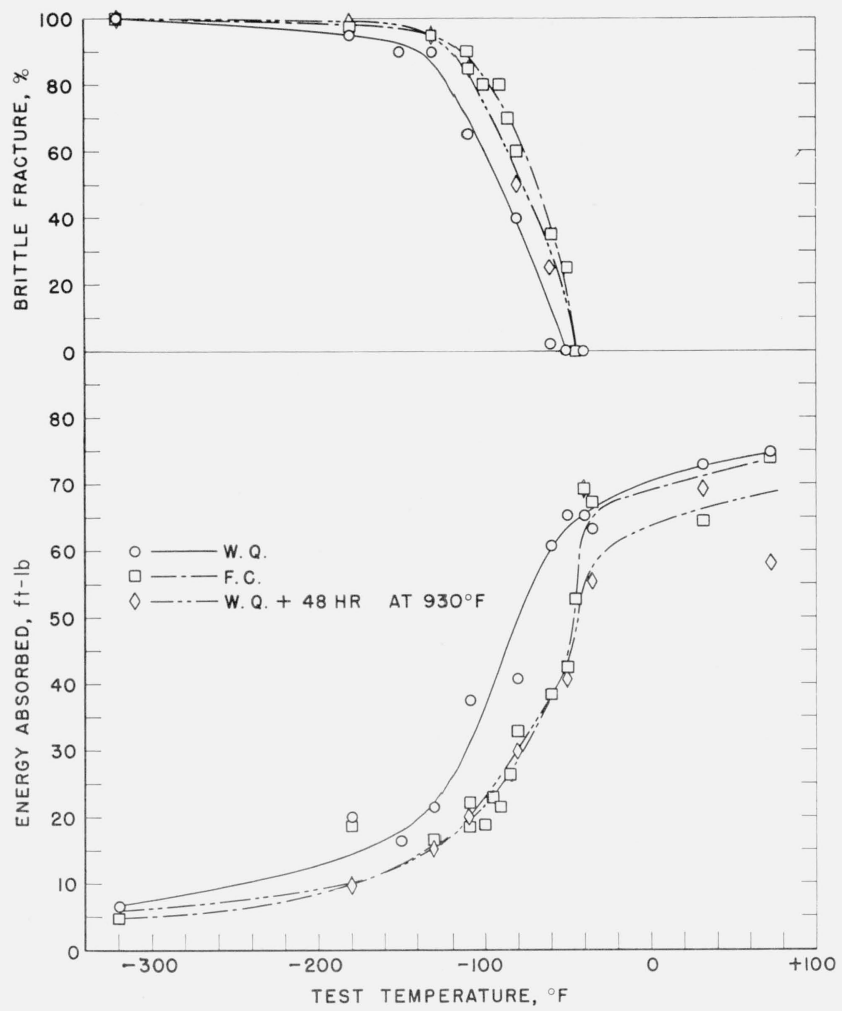

Figure 14. Impact curves for the National Bureau of Standards steel Mr48 (FeB plus FeTi).

NBS steel M747 contained 0.0018 percent of B, and hardenability was not increased over that of the base steel. The actual reason for the differences in susceptibility to temper brittleness of the two steels treated with ferroboron alone is not known.

The summary curves presented in figures 15 and 16 may be used to compare the effects of the various addition agents upon the impact properties of the steels. For the Bureau of Mines steels in all con- ditions of treatment investigated (fig. 15), steels M734, M735, and M736 (curves 4, 5, and 6, respectively) compare unfavorably with the base steel (curve 1). These three steels were treated either with addition agents or ferroalloys that contained titanium. The additions incorporated in steels M732, M733, and M737 (curves 2, 3, and 7, respectively) had but negligible effect upon the impact properties as compared with those of the base steel, and none of these additions contained titanium, although they contained boron or zirconium or both. For the NBS steels (fig. 16), the deleterious effect of the titanium additions, alone or with boron (curves $\mathrm{B}$ and $\mathrm{E}$ ), was not evident in the water-quenched steels. However, when isothermally treated at $930^{\circ} \mathrm{F}$ or when furnace-cooled from the tempering temperature, a slight deleterious effect was observed. The steel treated with ferroboron (M747, curve D) actually showed somewhat better impact properties than the base steel in each of the three conditions; the steel treated with ferrozirconium (M746, curve C) showed slightly better impact properties than the base steel in the water-quenched condition only.

Considering both series of steels (figs. 15 and 16), it may be concluded that, qualitatively, titanium has an adverse effect upon the impact properties of the steels as fully hardened and tempered at $1,200^{\circ} \mathrm{F}$ and that boron and zirconium do not.

The transition temperatures of the various steels were determined, using seven different criteria, as follows:

(1) The minimum temperature corresponding to 0 -percent-brittle fracture.

(2) The temperature corresponding to 50-percentbrittle fracture.

(3) The temperature corresponding to the average energy level. The average energy level was obtained by taking the arithmetic mean of the average value of the upper (maximum average) and lower (minimum average) flat portions of the curve of impact energy versus test temperature.

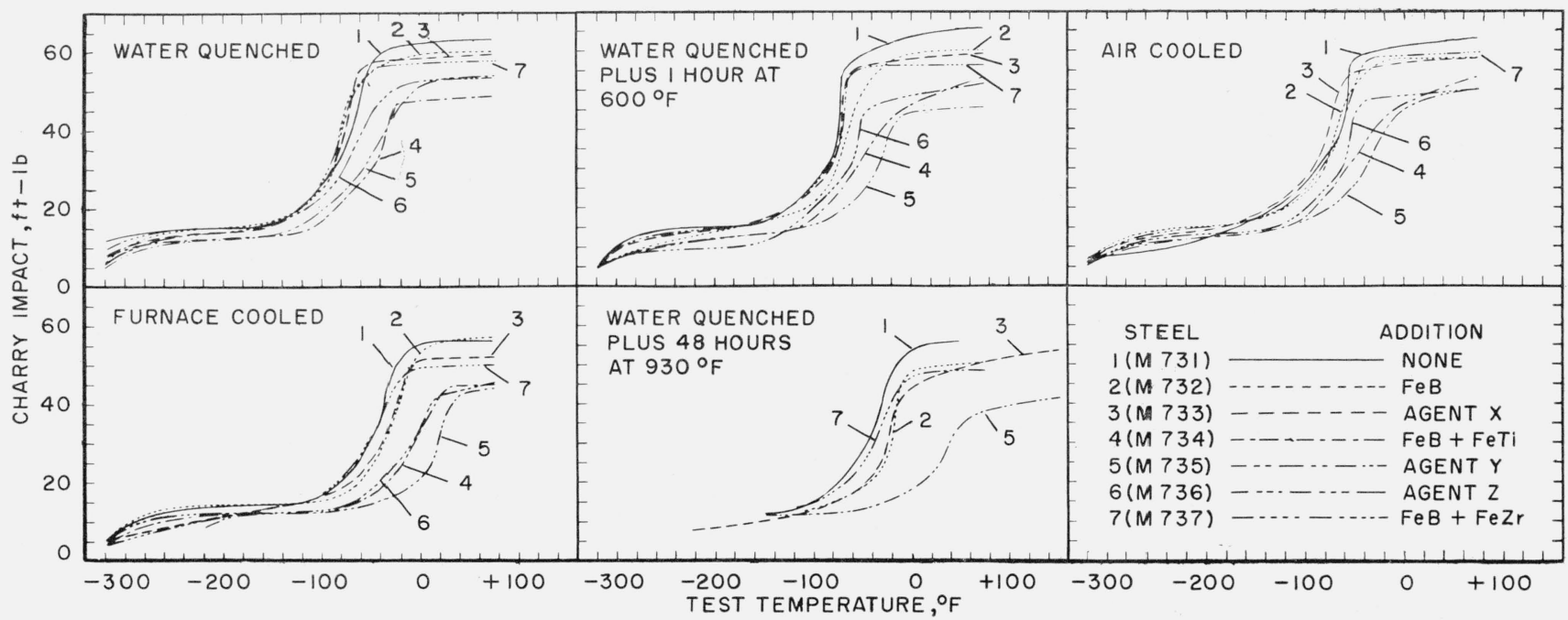

Figure 15. Summary of impact curves for the Bureau of Mines steels. 


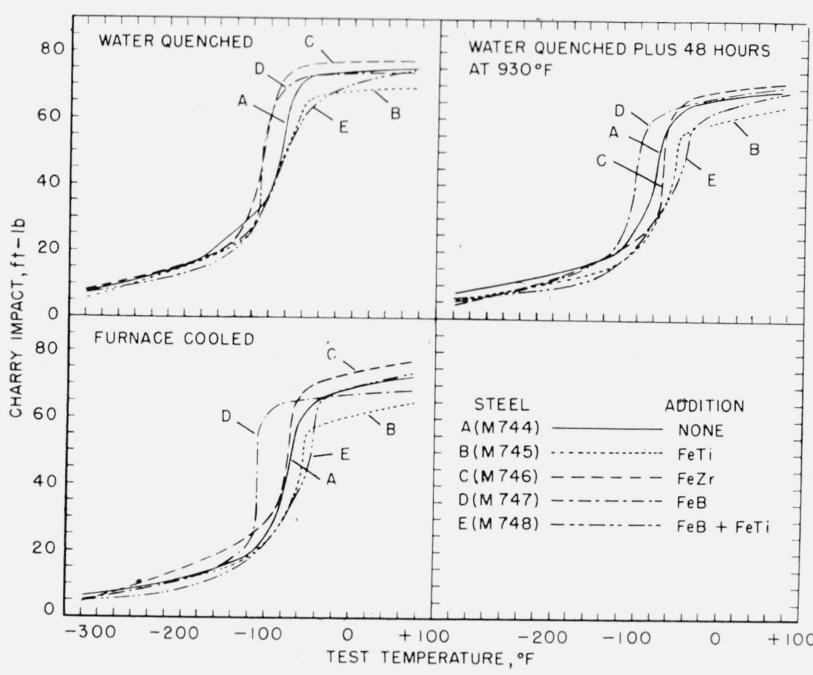

Figure 16. Summary of impact curves for the National Bureau of Standards steels.

(4) The temperature corresponding to 80 percent of the maximum average energy .

(5) The temperature corresponding to $40 \mathrm{ft}-\mathrm{lb}$.

(6) The temperature corresponding to $30 \mathrm{ft}-\mathrm{lb}$.

(7) The temperature corresponding to $20 \mathrm{ft}-\mathrm{lb}$.

The transition temperatures so derived, together with other pertinent data, are given in tables 4 and
5. For more ready comparison, the various transition temperatures are plotted as bar graphs in figures 17 to 23 , inclusive.

Obviously, the transition temperatures and the relative ratings of any two steels could be influenced by the transition criterion used. In spite of these variables, however, it is significant that, with all seven of the criteria utilized, the steels containing titanium (M734, M735, M736, M745, and M748) generally have higher transition temperatures than the corresponding base steels. A few exceptions to this generalization may be observed for the unembrittled conditions (water-quenched, water-quenched plus $1 \mathrm{hr}$ at $600^{\circ} \mathrm{F}$, and air-cooled); however, even in these cases the embrittling treatment caused a greater increase in the transition temperature of the steels containing titanium than was observed with the base steels. Although none of the steels contained as much zirconium as was desired, it was apparent that the zirconium present had no significant effect upon the impact properties.

Although several criteria for transition temperature have been used, it is believed that the criterion of 50-percent-brittle fracture possibly has the greatest significance. Using this criterion, figure 24 has been prepared so as to give a quick comparison of the shift in transition temperature caused by furnacecooling from the tempering temperature as compared with the corresponding water-quenched steel. In

TABLE 4. Transition temperatures-Bureau of Mines steels

\begin{tabular}{|c|c|c|c|c|c|c|c|c|c|c|c|c|c|c|}
\hline \multirow{3}{*}{$\begin{array}{r}\text { Steel } \\
\text { M731 (base) - }\end{array}$} & \multirow{3}{*}{$\begin{array}{l}\begin{array}{c}\text { Tempering treatment a } \\
1 \text { hr at } 1,200^{\circ} \mathrm{F}\end{array} \\
\qquad\left\{\begin{array}{l}\text { W.Q- } \\
\text { W.Q. }+1 \mathrm{hr} \text { at } 600^{\circ} \mathrm{F} \\
\text { A.C. } \\
\text { F.C } \\
\text { W.Q. }+48 \mathrm{hr} \text { at } 930^{\circ} \mathrm{F}\end{array}\right.\end{array}$} & \multirow{2}{*}{\multicolumn{2}{|c|}{$\begin{array}{l}0 \% \text {-brittle } \\
\text { fracture }\end{array}$}} & \multirow{2}{*}{\multicolumn{2}{|c|}{$\begin{array}{l}50 \% \text {-brittle } \\
\text { fracture }\end{array}$}} & \multicolumn{4}{|c|}{ A verage energy level } & \multirow{2}{*}{\multicolumn{2}{|c|}{$\begin{array}{l}80 \% \text { maximum } \\
\text { average energy }\end{array}$}} & \multirow{2}{*}{$\frac{40 \mathrm{ft}-\mathrm{lb}}{{ }^{\circ} \mathrm{F}}$} & \multirow{2}{*}{$\frac{30 \mathrm{ft}-\mathrm{lb}}{{ }^{\circ} \mathrm{F}}$} & \multirow{2}{*}{$\frac{20 \mathrm{ft}-\mathrm{ll}}{{ }^{\circ} \mathrm{F}}$} \\
\hline & & & & & & \multirow{2}{*}{$\begin{array}{c}\text { Max } \\
f t-l b \\
62 \\
65 \\
61 \\
56 \\
51\end{array}$} & \multirow{2}{*}{$\begin{array}{r}\text { Min } \\
\\
\text { ft-lb } \\
15 \\
15 \\
11 \\
14 \\
12\end{array}$} & \multirow{2}{*}{$\begin{array}{r}\text { A vg } \\
\\
\\
f t-l b \\
38 \\
40 \\
36 \\
35 \\
32\end{array}$} & \multirow{2}{*}{$\begin{array}{l}\text { Temp } \\
{ }^{\circ} F \\
-69 \\
-73 \\
-69 \\
-40 \\
-40\end{array}$} & & & & & \\
\hline & & $\begin{array}{l}{ }^{\circ} \mathrm{F} \\
-62 \\
-65 \\
-50 \\
-23 \\
-25\end{array}$ & $\begin{array}{r}f t-l b \\
44 \\
56 \\
57 \\
50 \\
44\end{array}$ & $\begin{array}{l}{ }^{\circ} \mathrm{F} \\
-79 \\
-80 \\
-76 \\
-54 \\
-45\end{array}$ & $\begin{array}{r}f t-l b \\
33 \\
32 \\
33 \\
28 \\
30\end{array}$ & & & & & $\begin{array}{r}f t-l b \\
50 \\
52 \\
49 \\
45 \\
41\end{array}$ & $\begin{array}{l}{ }^{\circ} \mathrm{F} \\
-58 \\
-70 \\
-55 \\
-31 \\
-29\end{array}$ & $\begin{array}{l}{ }^{\circ} \mathrm{F} \\
-67 \\
-73 \\
-62 \\
-35 \\
-29\end{array}$ & $\begin{array}{l}{ }^{\circ} \mathrm{F} \\
-87 \\
-85 \\
-85 \\
-50 \\
-44\end{array}$ & $\begin{array}{r}{ }^{\circ} F \\
-123 \\
-124 \\
-129 \\
-81 \\
-74\end{array}$ \\
\hline M732 (FeB) & $\left\{\begin{array}{l}\text { W.Q } \\
\text { W.Q. }+1 \text { hr at } 600^{\circ} \mathrm{F} \\
\text { A.C } \\
\text { F.C } \\
\text { W.Q. }+48 \text { hr at } 930^{\circ} \mathrm{F}\end{array}\right.$ & $\begin{array}{r}-57 \\
-54 \\
-54 \\
-13 \\
-9\end{array}$ & $\begin{array}{l}52 \\
46 \\
48 \\
47 \\
46\end{array}$ & $\begin{array}{l}-92 \\
-80 \\
-83 \\
-44 \\
-31\end{array}$ & $\begin{array}{l}27 \\
28 \\
28 \\
26 \\
23\end{array}$ & $\begin{array}{l}59 \\
59 \\
57 \\
55 \\
54\end{array}$ & $\begin{array}{l}15 \\
13 \\
15 \\
15 \\
13\end{array}$ & $\begin{array}{l}37 \\
36 \\
36 \\
35 \\
34\end{array}$ & $\begin{array}{l}-82 \\
-68 \\
-72 \\
-28 \\
-18\end{array}$ & $\begin{array}{l}47 \\
47 \\
46 \\
44 \\
43\end{array}$ & $\begin{array}{l}-71 \\
-53 \\
-59 \\
-17 \\
-11\end{array}$ & $\begin{array}{l}-80 \\
-63 \\
-68 \\
-21 \\
-15\end{array}$ & $\begin{array}{l}-86 \\
-76 \\
-79 \\
-36 \\
-21\end{array}$ & $\begin{array}{r}-123 \\
-108 \\
-119 \\
-62 \\
-43\end{array}$ \\
\hline M733 (agent X) .. & $\left\{\begin{array}{l}\text { W.Q } \\
\text { W.Q. }+1 \text { hr at } 600^{\circ} \mathrm{F} \\
\text { A.C } \\
\text { F.C } \\
\text { W.Q. }+48 \text { hr at } 930^{\circ} \mathrm{F}\end{array}\right.$ & $\begin{array}{l}-65 \\
-65 \\
-62 \\
-17 \\
-15\end{array}$ & $\begin{array}{l}52 \\
54 \\
52 \\
46 \\
40\end{array}$ & $\begin{array}{l}-89 \\
-76 \\
-90 \\
-48 \\
-36\end{array}$ & $\begin{array}{l}30 \\
33 \\
30 \\
26 \\
22\end{array}$ & $\begin{array}{l}58 \\
58 \\
57 \\
51 \\
50\end{array}$ & $\begin{array}{l}14 \\
14 \\
14 \\
11 \\
10\end{array}$ & $\begin{array}{l}36 \\
36 \\
36 \\
31 \\
30\end{array}$ & $\begin{array}{l}-79 \\
-73 \\
-80 \\
-36 \\
-24\end{array}$ & $\begin{array}{l}46 \\
46 \\
46 \\
41 \\
40\end{array}$ & $\begin{array}{l}-69 \\
-68 \\
-68 \\
-23 \\
-13\end{array}$ & $\begin{array}{l}-75 \\
-71 \\
-75 \\
-24 \\
-13\end{array}$ & $\begin{array}{l}-89 \\
-83 \\
-91 \\
-38 \\
-24\end{array}$ & $\begin{array}{r}-122 \\
-127 \\
-138 \\
-73 \\
-45\end{array}$ \\
\hline $\mathrm{M} 734(\mathrm{FeB}+\mathrm{FeTi})$ & $\left\{\begin{array}{l}\text { W.Q } \\
\text { W.Q. }+1 \text { hr at } 600^{\circ} \mathrm{F} \\
\text { A.C } \\
\text { F.C } \\
\text { W.Q. }+48 \text { hr at } 930^{\circ} \mathrm{F}\end{array}\right.$ & $\begin{array}{l}-30 \\
-20 \\
-30 \\
+10\end{array}$ & $\begin{array}{l}41 \\
42 \\
44 \\
38\end{array}$ & $\begin{array}{l}-52 \\
-44 \\
-64 \\
-16\end{array}$ & $\begin{array}{l}29 \\
34 \\
27 \\
26\end{array}$ & $\begin{array}{l}48 \\
49 \\
52 \\
44\end{array}$ & $\begin{array}{l}13 \\
12 \\
13 \\
12\end{array}$ & $\begin{array}{l}30 \\
30 \\
32 \\
28\end{array}$ & $\begin{array}{l}-46 \\
-53 \\
-47 \\
-11\end{array}$ & $\begin{array}{l}38 \\
39 \\
42 \\
35\end{array}$ & $\begin{array}{r}-34 \\
-31 \\
-32 \\
+5\end{array}$ & $\begin{array}{l}-32 \\
-28 \\
-33 \\
+16\end{array}$ & $\begin{array}{l}-48 \\
-54 \\
-54 \\
-6\end{array}$ & $\begin{array}{l}-85 \\
-86 \\
-90 \\
-34\end{array}$ \\
\hline M735 (agent Y) & $\left\{\begin{array}{l}\text { W.Q } \\
\text { W.Q. }+1 \text { hr at } 600^{\circ} \mathrm{F} \\
\text { A.C } \\
\text { F.C } \\
\text { W.Q. }+48 \text { hr at } 930^{\circ} \mathrm{F}\end{array}\right.$ & $\begin{array}{r}-23 \\
-18 \\
-6 \\
+32 \\
+49\end{array}$ & $\begin{array}{l}45 \\
41 \\
43 \\
40 \\
34\end{array}$ & $\begin{array}{r}-58 \\
-41 \\
-43 \\
+7 \\
+13\end{array}$ & $\begin{array}{l}30 \\
26 \\
28 \\
24 \\
20\end{array}$ & $\begin{array}{l}53 \\
44 \\
48 \\
43 \\
40\end{array}$ & $\begin{array}{l}13 \\
13 \\
13 \\
12 \\
12\end{array}$ & $\begin{array}{l}33 \\
28 \\
30 \\
28 \\
26\end{array}$ & $\begin{array}{l}-50 \\
-37 \\
-37 \\
+14 \\
+31\end{array}$ & $\begin{array}{l}42 \\
35 \\
38 \\
34 \\
32\end{array}$ & $\begin{array}{l}-30 \\
-26 \\
-22 \\
+21 \\
+42\end{array}$ & $\begin{array}{r}-34 \\
-20 \\
-17 \\
+30 \\
+115\end{array}$ & $\begin{array}{l}-59 \\
-34 \\
-38 \\
+17 \\
+38\end{array}$ & $\begin{array}{r}-99 \\
-66 \\
-77 \\
-7 \\
+11\end{array}$ \\
\hline M736 (agent Z) -. & $\left\{\begin{array}{l}\text { W.Q } \\
\text { W.Q. }+1 \text { hr at } 600^{\circ} \mathrm{F} \\
\text { A.C. } \\
\text { F.C } \\
\text { W.Q. }+48 \text { hr at } 930^{\circ} \mathrm{F}\end{array}\right.$ & $\begin{array}{l}-49 \\
-43 \\
-49 \\
+11\end{array}$ & $\begin{array}{l}44 \\
45 \\
44 \\
40\end{array}$ & $\begin{array}{l}-83 \\
-71 \\
-68 \\
-20\end{array}$ & $\begin{array}{l}28 \\
27 \\
28 \\
26\end{array}$ & $\begin{array}{l}53 \\
49 \\
49 \\
44\end{array}$ & $\begin{array}{l}14 \\
10 \\
13 \\
12\end{array}$ & $\begin{array}{l}34 \\
30 \\
31 \\
28\end{array}$ & $\begin{array}{l}-69 \\
-65 \\
-61 \\
-14\end{array}$ & $\begin{array}{l}43 \\
39 \\
39 \\
35\end{array}$ & $\begin{array}{r}-51 \\
-53 \\
-52 \\
+2\end{array}$ & $\begin{array}{l}-58 \\
-52 \\
-51 \\
+10\end{array}$ & $\begin{array}{r}-76 \\
-63 \\
-62 \\
-9\end{array}$ & $\begin{array}{r}-116 \\
-98 \\
-97 \\
-42\end{array}$ \\
\hline M737 (FeB+FeZr) & $\left\{\begin{array}{l}W \cdot Q \\
W \cdot Q \cdot+1 \mathrm{hr} \text { at } 600^{\circ} \mathrm{F} \\
\text { A.C } \\
\text { F.C } \\
W \cdot Q \cdot+48 \text { hr at } 930^{\circ} \mathrm{F}\end{array}\right.$ & $\begin{array}{l}-50 \\
-65 \\
-50 \\
-24 \\
-13\end{array}$ & $\begin{array}{l}54 \\
53 \\
50 \\
46 \\
44\end{array}$ & $\begin{array}{l}-87 \\
-87 \\
-77 \\
-55 \\
-52\end{array}$ & $\begin{array}{l}33 \\
28 \\
32 \\
29 \\
24\end{array}$ & $\begin{array}{l}57 \\
56 \\
58 \\
49 \\
47\end{array}$ & $\begin{array}{l}15 \\
15 \\
15 \\
10 \\
14\end{array}$ & $\begin{array}{l}36 \\
36 \\
36 \\
30 \\
30\end{array}$ & $\begin{array}{l}-83 \\
-73 \\
-67 \\
-53 \\
-37\end{array}$ & $\begin{array}{l}46 \\
45 \\
46 \\
39 \\
38\end{array}$ & $\begin{array}{l}-72 \\
-66 \\
-55 \\
-34 \\
-25\end{array}$ & $\begin{array}{l}-78 \\
-68 \\
-62 \\
-32 \\
-21\end{array}$ & $\begin{array}{l}-92 \\
-84 \\
-81 \\
-52 \\
-37\end{array}$ & $\begin{array}{r}-123 \\
-120 \\
-123 \\
-84 \\
-65\end{array}$ \\
\hline
\end{tabular}

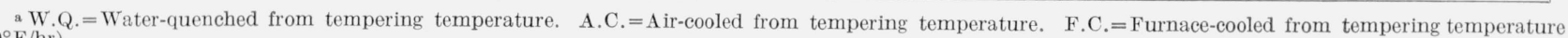
$\left(30^{\circ} \mathrm{F} / \mathrm{hr}\right)$ 
TABLE 5. Transition temperatures-NBS steels

\begin{tabular}{|c|c|c|c|c|c|c|c|c|c|c|c|c|c|c|}
\hline \multirow{3}{*}{$\begin{array}{r}\text { Steel } \\
\text { M744 (base) }\end{array}$} & \multirow{3}{*}{ 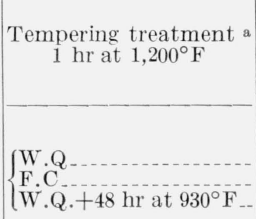 } & \multirow{2}{*}{\multicolumn{2}{|c|}{$\begin{array}{l}0 \% \text {-brittle } \\
\text { fracture }\end{array}$}} & \multirow{2}{*}{\multicolumn{2}{|c|}{$\begin{array}{l}50 \% \text {-brittle } \\
\text { fracture }\end{array}$}} & \multicolumn{4}{|c|}{ A verage energy level } & \multirow{2}{*}{\multicolumn{2}{|c|}{$\begin{array}{l}80 \% \text { maximum } \\
\text { average energy }\end{array}$}} & \multirow{3}{*}{$\begin{array}{l}40 \mathrm{ft}-\mathrm{lb} \\
{ }^{\circ} \mathrm{F} \\
-96 \\
-77 \\
-80\end{array}$} & \multirow{3}{*}{$\begin{array}{l}30 \mathrm{ft}-\mathrm{lb} \\
\\
{ }^{\circ} \mathrm{F} \\
-122 \\
-88 \\
-98\end{array}$} & \multirow{3}{*}{\begin{tabular}{|l}
$20 \mathrm{ft}-\mathrm{lb}$ \\
\\
\\
$\circ \mathrm{F}$ \\
-169 \\
-113 \\
-128
\end{tabular}} \\
\hline & & & & & & \multirow{2}{*}{$\begin{array}{r}\text { Max } \\
f t-l b \\
74 \\
68 \\
67\end{array}$} & \multirow{2}{*}{$\begin{array}{r}\text { Min } \\
f t-l b \\
13 \\
10 \\
12\end{array}$} & \multirow{2}{*}{$\begin{array}{r}\text { A vg } \\
f t-l b \\
43 \\
39 \\
40\end{array}$} & \multirow{2}{*}{$\begin{array}{l}\text { Temp } \\
{ }^{\circ} \mathrm{F} \\
-92 \\
-78 \\
-81\end{array}$} & & & & & \\
\hline & & $\begin{array}{l}{ }^{\circ} \mathrm{F} \\
-74 \\
-52 \\
-57\end{array}$ & $\begin{array}{r}f t-l b \\
66 \\
62 \\
62\end{array}$ & $\begin{array}{l}{ }^{\circ} F \\
-101 \\
-82 \\
-85\end{array}$ & $\begin{array}{r}f t-l b \\
37 \\
34 \\
36\end{array}$ & & & & & $\begin{array}{r}f t-l b \\
59 \\
54 \\
54\end{array}$ & $\begin{array}{l}{ }^{\circ} \mathrm{F} \\
-79 \\
-65 \\
-72\end{array}$ & & & \\
\hline M745 (FeTi) & $\left\{\begin{array}{l}\mathrm{W} \cdot \mathrm{Q} \\
\mathrm{F} \cdot \mathrm{C} \\
\mathrm{W} \cdot \mathrm{Q} \cdot+48 \mathrm{hr} \text { at } 930^{\circ} \mathrm{F}\end{array}\right.$ & $\begin{array}{l}-77 \\
-40 \\
-48\end{array}$ & $\begin{array}{l}52 \\
58 \\
56\end{array}$ & $\begin{array}{l}-95 \\
-65 \\
-72\end{array}$ & $\begin{array}{l}40 \\
33 \\
33\end{array}$ & $\begin{array}{l}68 \\
62 \\
59\end{array}$ & $\begin{array}{r}14 \\
9 \\
10\end{array}$ & $\begin{array}{l}41 \\
36 \\
34\end{array}$ & $\begin{array}{l}-94 \\
-62 \\
-69\end{array}$ & $\begin{array}{l}54 \\
49 \\
47\end{array}$ & $\begin{array}{l}-73 \\
-53 \\
-56\end{array}$ & $\begin{array}{l}-96 \\
-57 \\
-61\end{array}$ & $\begin{array}{l}-111 \\
-70 \\
-78\end{array}$ & $\begin{array}{l}-151 \\
-104 \\
-109\end{array}$ \\
\hline M746 (FeZr) .. & $\left\{\begin{array}{l}\mathrm{W} \cdot \mathrm{Q} \\
\mathrm{F} \cdot \mathrm{C} \\
\mathrm{W} \cdot \mathrm{Q} \cdot+48 \mathrm{hr} \text { at } 930^{\circ} \mathrm{F}\end{array}\right.$ & $\begin{array}{l}-98 \\
-65 \\
-64\end{array}$ & $\begin{array}{l}62 \\
63 \\
60\end{array}$ & $\begin{array}{r}-110 \\
-83 \\
-86\end{array}$ & $\begin{array}{l}45 \\
35 \\
28\end{array}$ & $\begin{array}{l}77 \\
73 \\
70\end{array}$ & $\begin{array}{l}13 \\
12 \\
14\end{array}$ & $\begin{array}{l}45 \\
42 \\
42\end{array}$ & $\begin{array}{r}-110 \\
-77 \\
-71\end{array}$ & $\begin{array}{l}61 \\
58 \\
56\end{array}$ & $\begin{array}{l}-99 \\
-69 \\
-68\end{array}$ & $\begin{array}{r}-114 \\
-78 \\
-72\end{array}$ & $\begin{array}{l}-126 \\
-93 \\
-81\end{array}$ & $\begin{array}{l}-156 \\
-144 \\
-132\end{array}$ \\
\hline $\mathrm{M} 747(\mathrm{FeB})$. & $\left\{\begin{array}{l}\mathrm{W} \cdot \mathrm{Q} \\
\mathrm{F} \cdot \mathrm{C} \\
\mathrm{W} \cdot \mathrm{Q} .+48 \mathrm{hr} \text { at } 930^{\circ} \mathrm{F}\end{array}\right.$ & $\begin{array}{l}-106 \\
-106 \\
-106\end{array}$ & $\begin{array}{l}55 \\
57 \\
38\end{array}$ & $\begin{array}{l}-110 \\
-110 \\
-110\end{array}$ & $\begin{array}{l}42 \\
30 \\
33\end{array}$ & $\begin{array}{l}73 \\
66 \\
67\end{array}$ & $\begin{array}{l}14 \\
10 \\
10\end{array}$ & $\begin{array}{l}43 \\
38 \\
38\end{array}$ & $\begin{array}{l}-110 \\
-108 \\
-106\end{array}$ & $\begin{array}{l}58 \\
54 \\
54\end{array}$ & $\begin{array}{r}-103 \\
-108 \\
-97\end{array}$ & $\begin{array}{l}-110 \\
-108 \\
-105\end{array}$ & $\begin{array}{l}-115 \\
-109 \\
-113\end{array}$ & $\begin{array}{l}-158 \\
-113 \\
-134\end{array}$ \\
\hline $\mathrm{M} 748(\mathrm{FeB}+\mathrm{FeTi}) \ldots$ & $\left\{\begin{array}{l}\mathrm{W} \cdot \mathrm{Q} \\
\mathrm{F} \cdot \mathrm{C} \cdot \mathrm{Q} \cdot+48 \mathrm{hr} \text { at } 930^{\circ} \mathrm{F}\end{array}\right.$ & $\begin{array}{l}-51 \\
-44 \\
-43\end{array}$ & $\begin{array}{l}63 \\
60 \\
52\end{array}$ & $\begin{array}{l}-90 \\
-67 \\
-76\end{array}$ & $\begin{array}{l}43 \\
34 \\
32\end{array}$ & $\begin{array}{l}70 \\
70 \\
65\end{array}$ & $\begin{array}{r}12 \\
8 \\
9\end{array}$ & $\begin{array}{l}41 \\
39 \\
37\end{array}$ & $\begin{array}{l}-93 \\
-58 \\
-63\end{array}$ & $\begin{array}{l}56 \\
56 \\
52\end{array}$ & $\begin{array}{l}-69 \\
-42 \\
-43\end{array}$ & $\begin{array}{l}-95 \\
-56 \\
-56\end{array}$ & $\begin{array}{r}-111 \\
-77 \\
-80\end{array}$ & $\begin{array}{l}-139 \\
-106 \\
-110\end{array}$ \\
\hline
\end{tabular}
$\left.30^{\circ} \mathrm{F} / \mathrm{hr}\right)$

assessing the magnitude of these shifts, which are a direct measure of temper embrittlement, consideration must also be given to the effects the addition agents have upon the transition temperature of the water-quenched steels. For instance, in figure 24, the transition temperature of steel M734 (FeB+ $\mathrm{FeTi}$ ) has been raised $36 \mathrm{deg} \mathrm{F}$ by furnace-cooling as compared with water-quenching from the tempering temperature and the corresponding shift in steel M737 (FeB + FeZr) was only $32 \mathrm{deg} \mathrm{F}$ - certainly an insignificant difference. However, the transition temperature of the titanium-treated steel M734 as water-quenched was $-52^{\circ} \mathrm{F}$ - a value considerably higher than that for the zirconium-treated steel M737 $\left(-87^{\circ} \mathrm{F}\right)$. Apparently the titanium addition was sufficient to raise the transition temperature of the water-quenched steel so much that the additional shift caused by furnace-cooling appeared innocuous. Indeed, the transition temperature of the titaniumtreated steel M734 as water-quenched was actually higher than that of the zirconium-treated steel M737 as furnace-cooled $\left(-52^{\circ}\right.$ and $-55^{\circ} \mathrm{F}$, respectively).

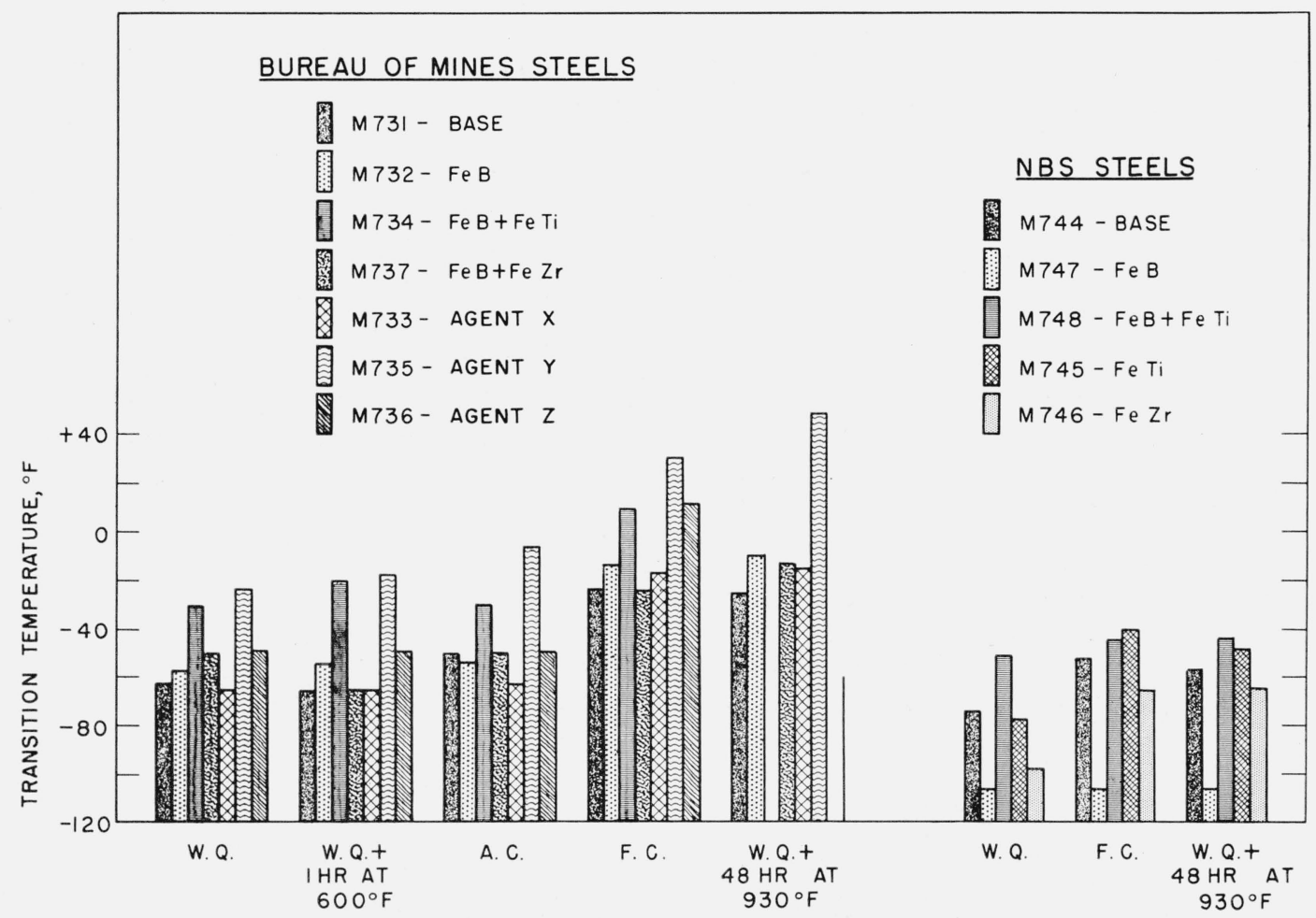

FIGURE 17. Transition temperatures of the various steels (transition criterion, $0 \%$-brittle fracture). 


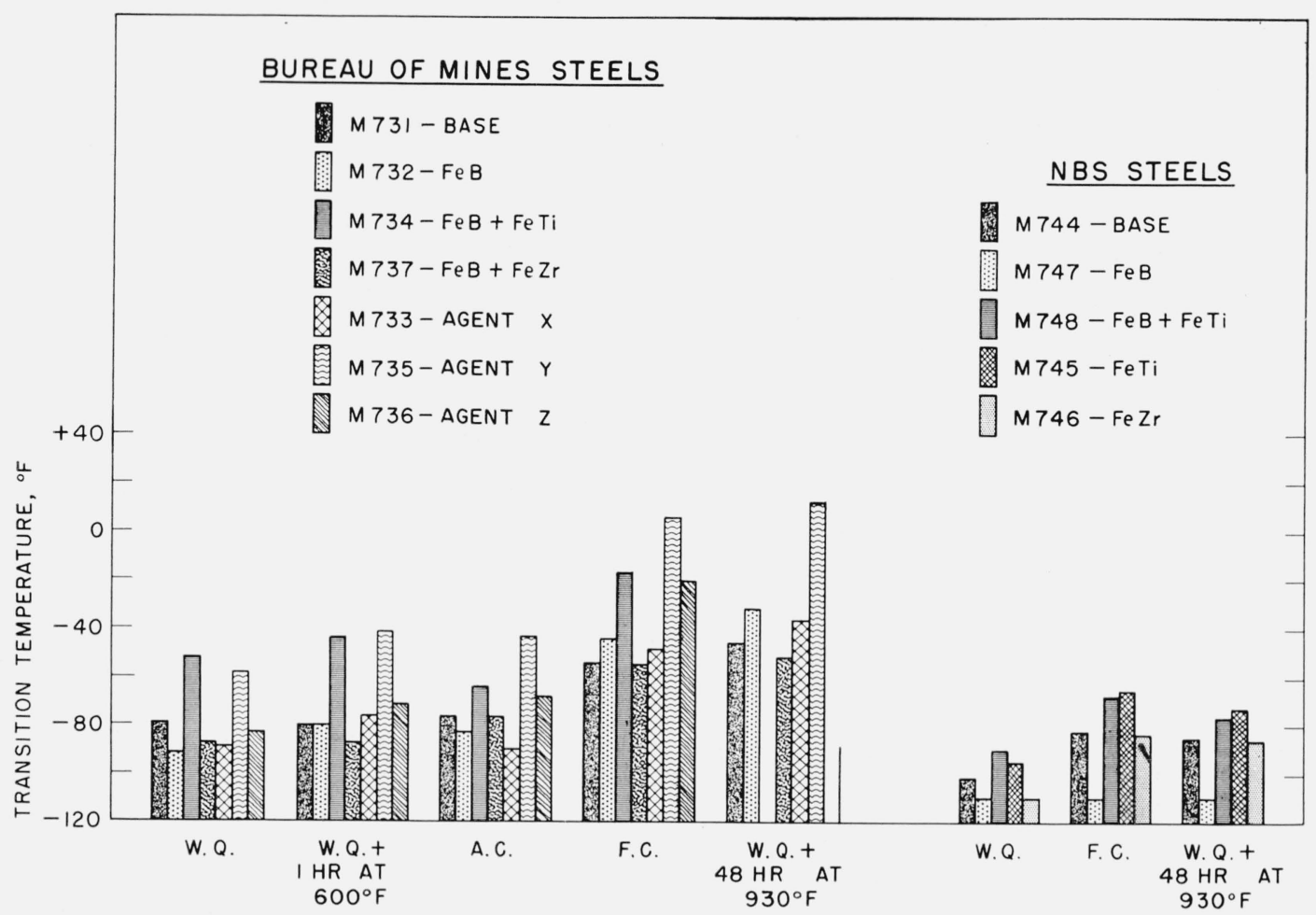

FIGURE 18. Transition temperatures of the various steels (transition criterion, 50\%-brittle fracture).

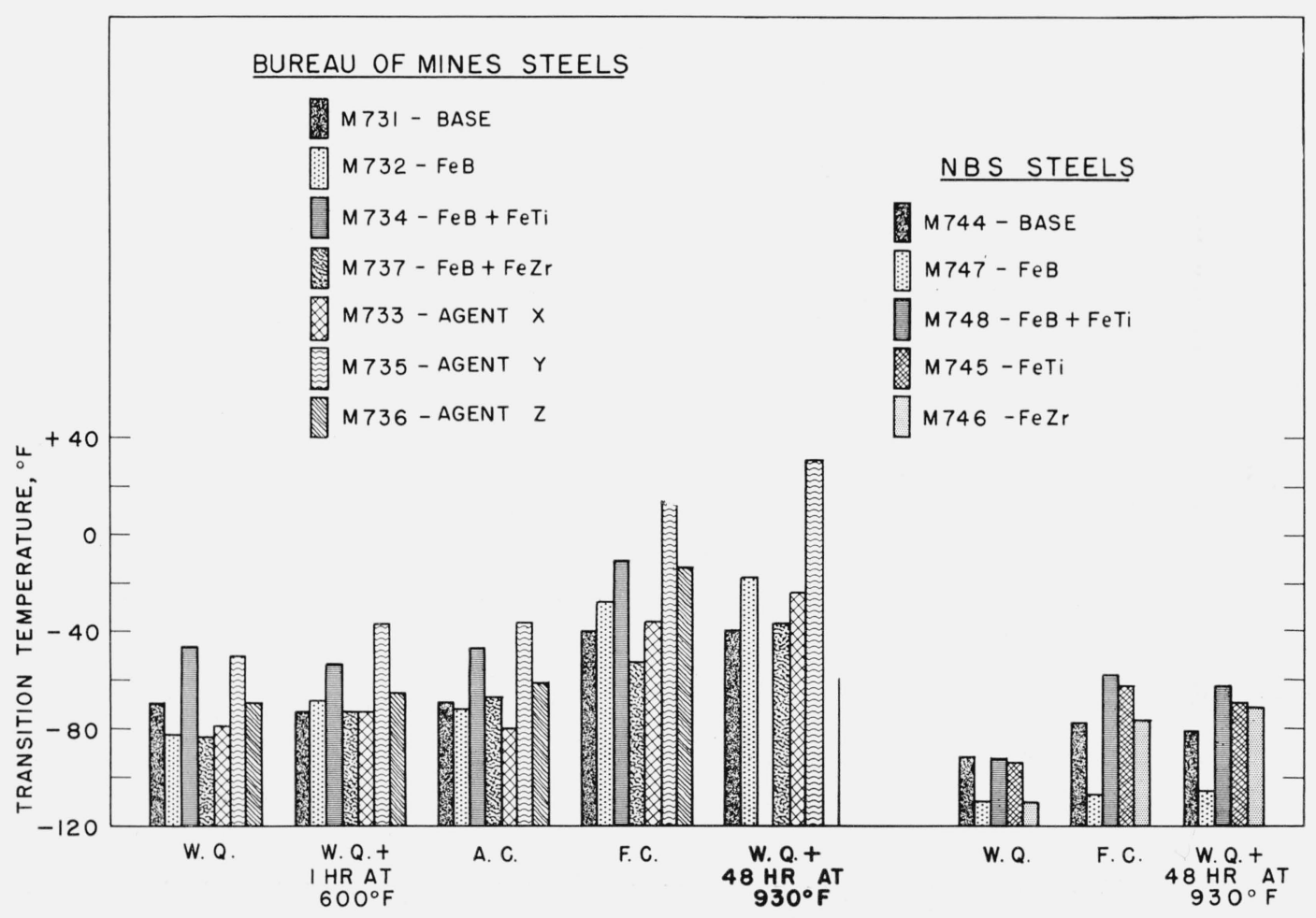

FIGURE 19. Transition temperatures of the various steels (transition criterion, average energy level). 


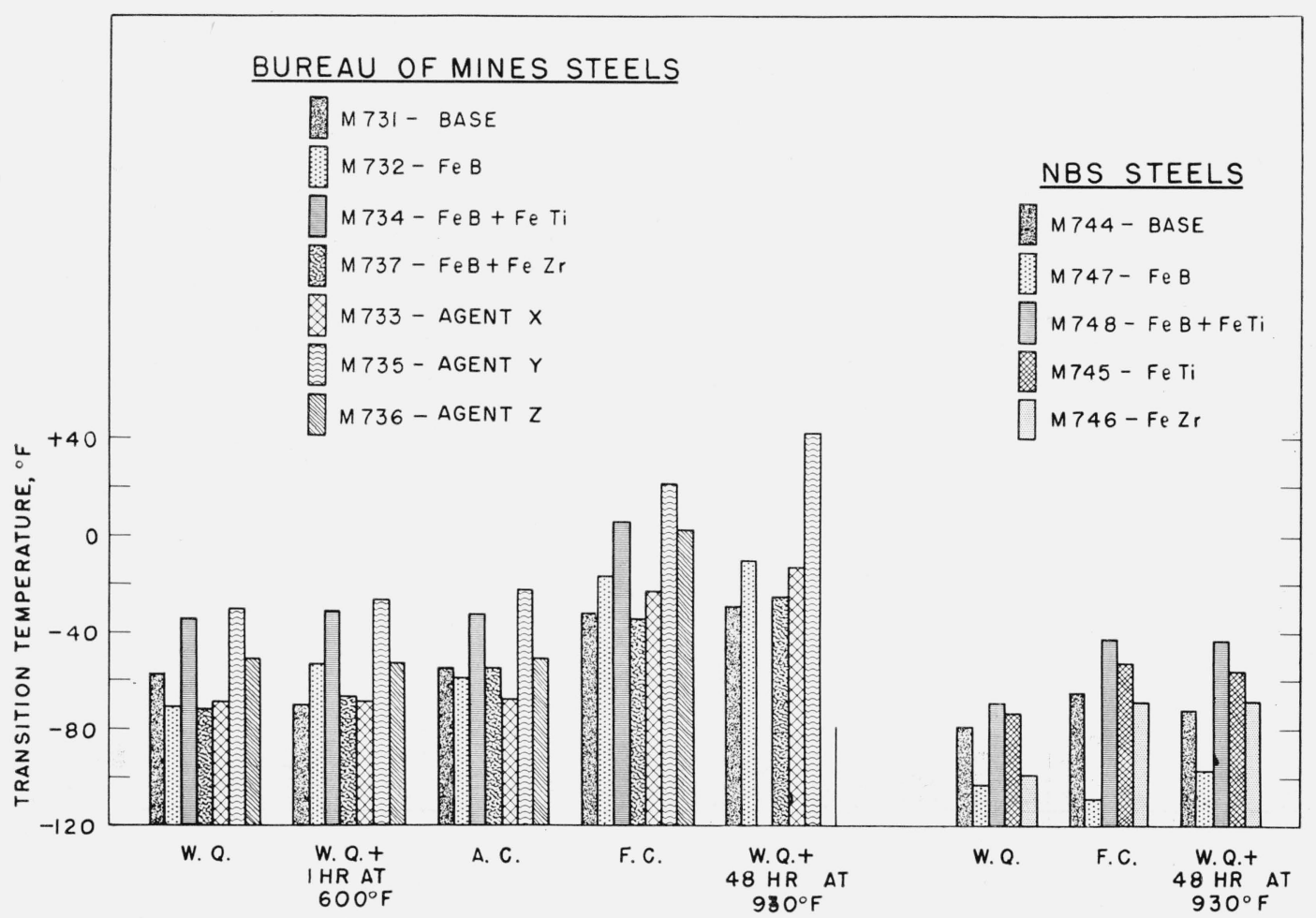

Figure 20. Transition temperatures of the various steels (transition criterion, $80 \%$ of the maximum average energy).

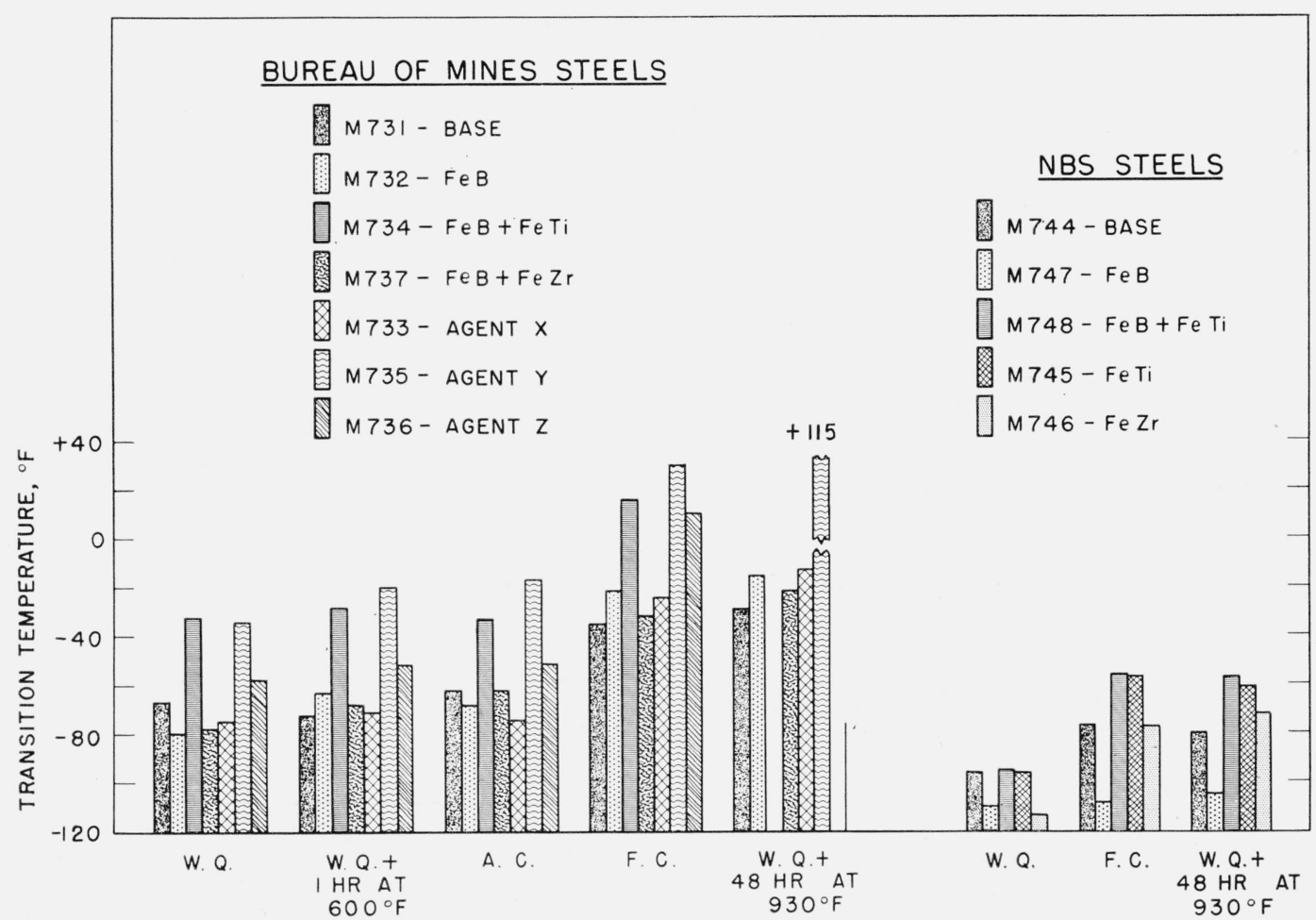

FIGURE 21. Transition temperatures of the various steels (transition criterion, $40 \mathrm{ft}-\mathrm{lb}$ ). 


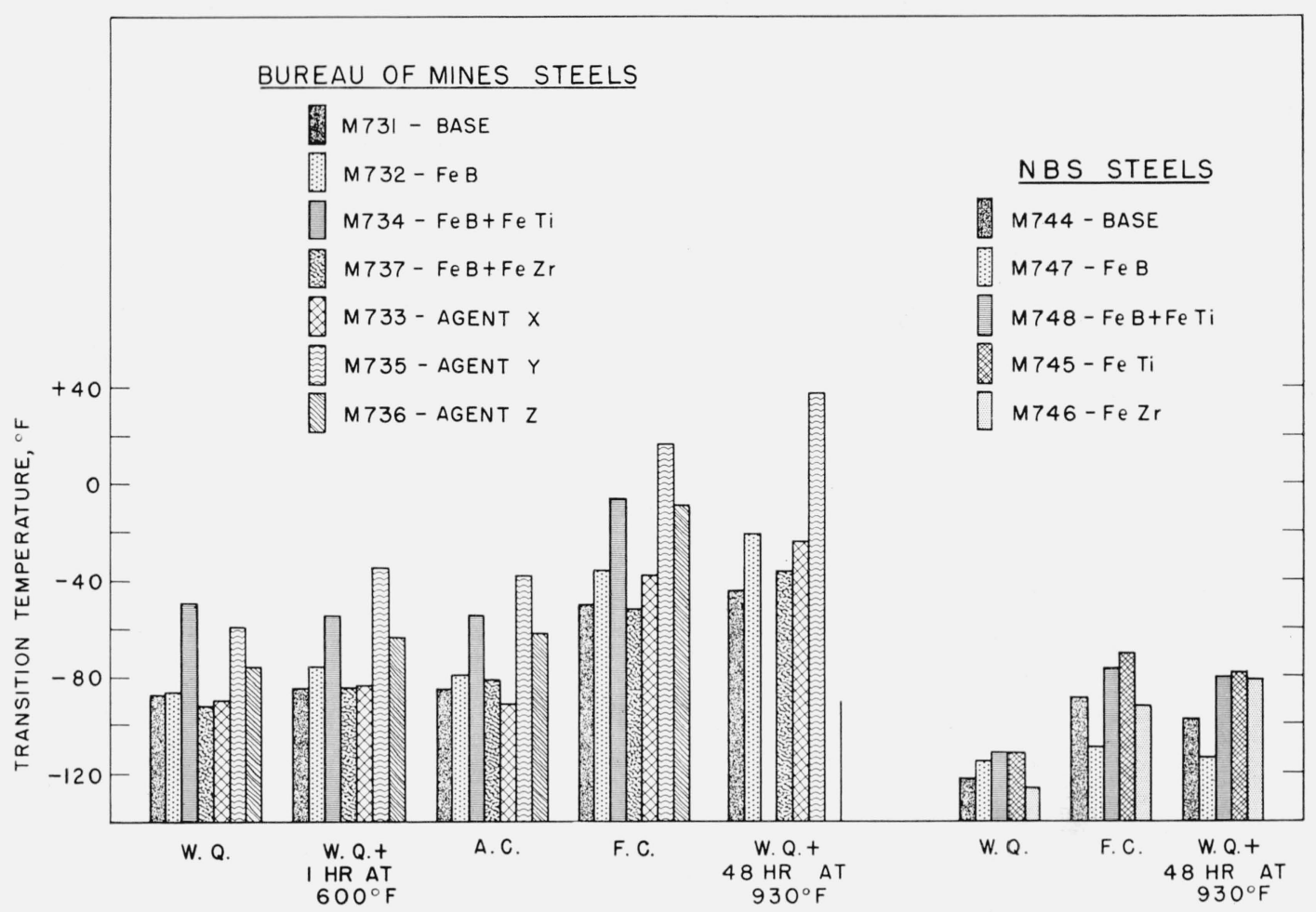

Figure 22. Transition temperatures of the various steels (transition criterion, $30 \mathrm{ft}-\mathrm{lb}$ ).

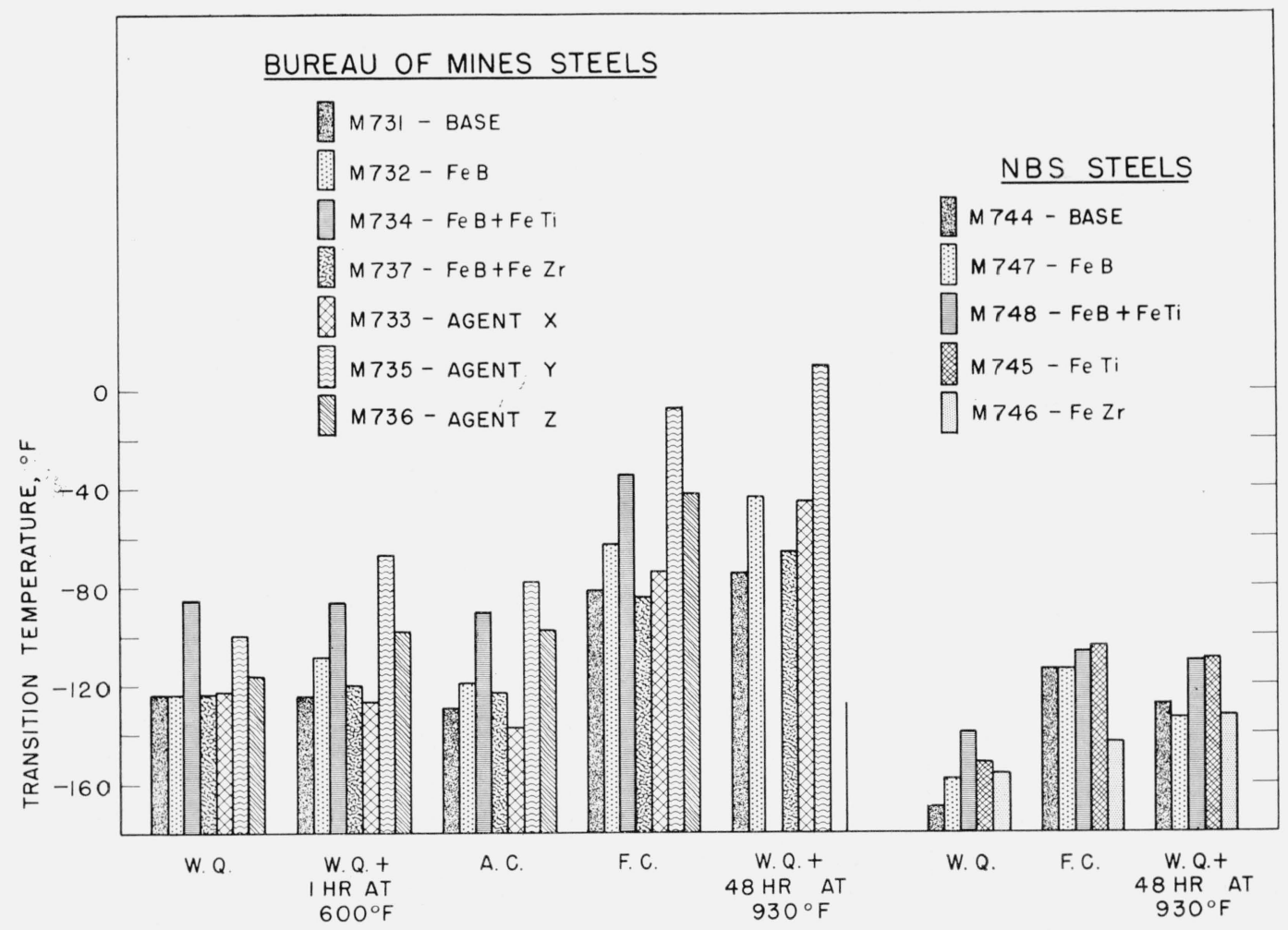

FIgURE 23. Transition temperatures of the various steels (transition criterion, $20 \mathrm{ft-lb}$ ). 


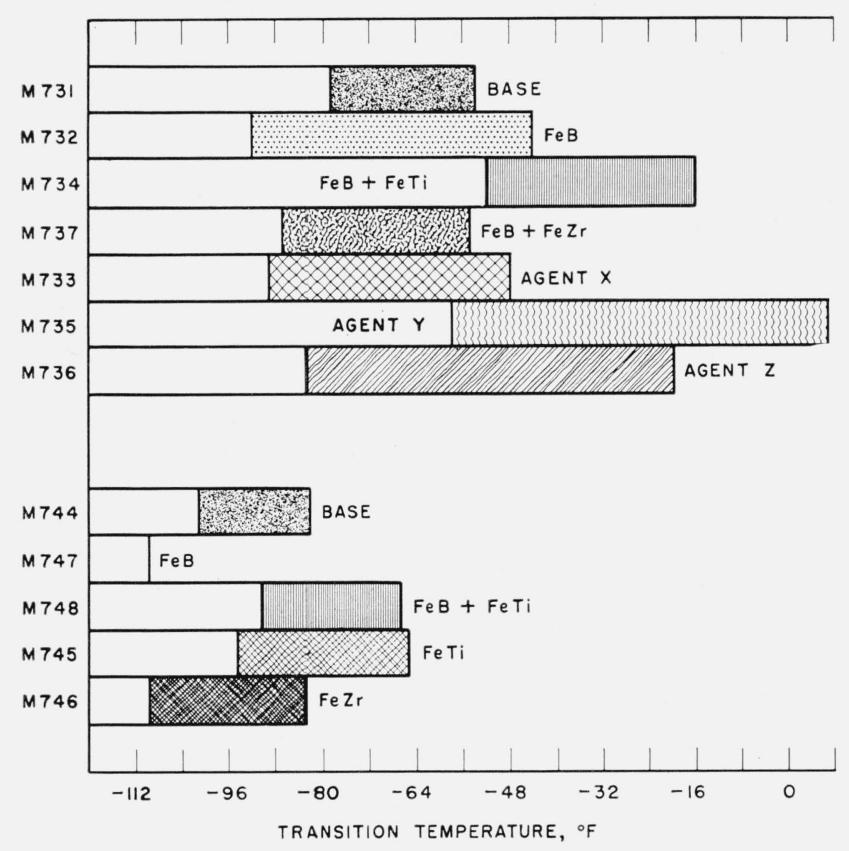

FIGURE 24. Increase in transition temperature $(50 \%$-brittle fracture) of the furnace-cooled steels as compared with the corresponding water-quenched steels.

Open bars give the transition temperatures of the water-quenched steels; shaded bars those of the furnace-cooled steels. The lengths of the shaded bars, therefore, indicate the increase in transition temperatures. Steel M747 had the therefore, indicate the increase in transition temperatures. Stee
same transition temperature in both conditions of treatment.

It is obvious that any attempt to measure the effect of the addition agents in causing temper brittleness merely by calculating the shift in transition temperature caused by the embrittling treatment on the individual steels can give erroneous conclusions as to the effect of these addition agents upon the impact properties in general.

In figure 25 these same data have been replotted to show the shift in transition temperature caused by furnace-cooling the various steels as compared with the water-quenched base steel. Here the deleterious effects of the titanium additions on the impact properties stand out clearly. The steels so treated were M734 (FeB + Fe'Ti), M735 (addition agent Y), M736 (addition agent Z), M748 $(\mathrm{FeB}+\mathrm{Fe} \mathrm{Ti})$, and M745 (Fe'Ti). The additions incorporated in the other steels had a negligible effect upon the impact properties. The same general picture would have been evident had the isothermally treated steels been compared with the water-quenched steels.

Even though the same general trends were observed both in the series of steels melted at the Bureau of Mines and at the National Bureau of Standards, the impact properties of the NBS steels were markedly superior to those of the Bureau of Mines steels. The cause of this difference in impact properties is not clear. It is possible that the slightly lower carbon content of the NBS steels may be partly responsible.

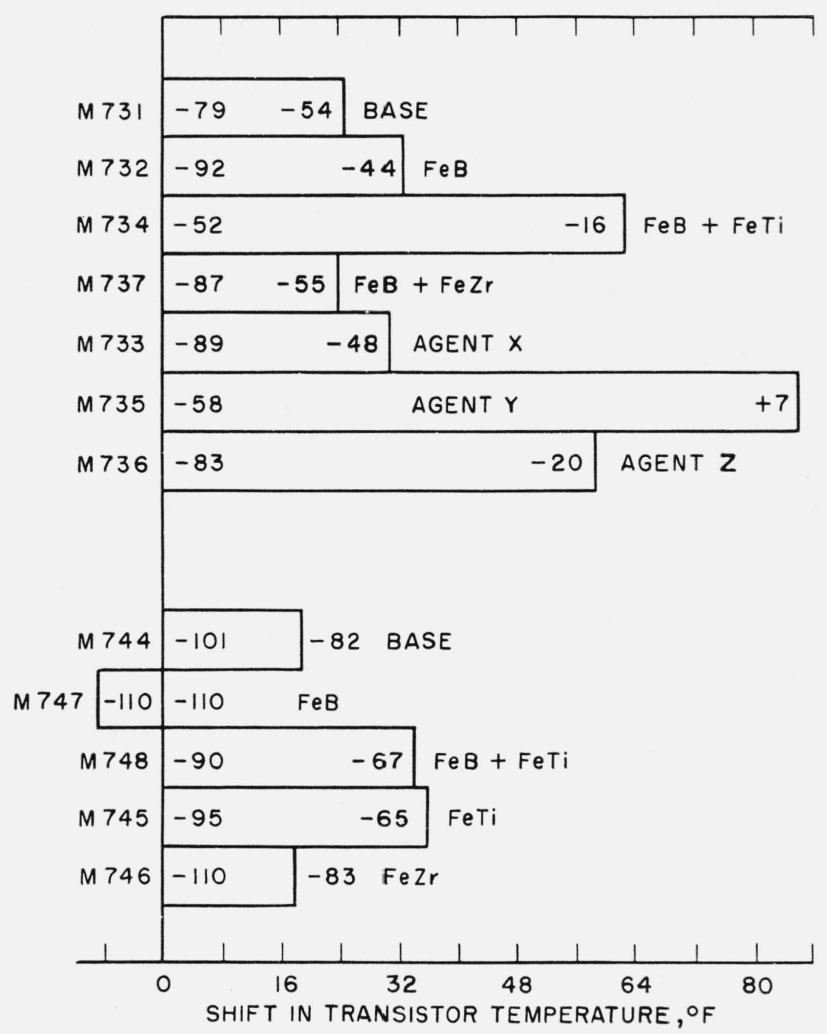

FiguRE 25. Increase in transition temperature $(50 \%$-brittle fracture) of the furnace-cooled steels as compared with the water-quenched base steel.

Figures in bars indicate the actual transition temperatures of the various steels both as water-quenched (lower temperature) and as furnace-cooled (higher temperature).

\section{Summary and Conclusions}

Two series of steels, melted to the base composition of 8140 , were studied to ascertain whether titanium and zirconium (present in many commercial boron addition agents) had any adverse effect upon the impact properties of the base steels, particularly with reference to temper brittleness. All steels were given the same hardening treatment $(1 / 2 \mathrm{hr}$ at $1,600^{\circ} \mathrm{F}$, oil quench) and were tempered $1 \mathrm{hr}$ at $1,200^{\circ} \mathrm{F}$. The rate of cooling from the tempering temperature was varied so as to develop temper brittleness and an isothermal embrittling treatment also was employed.

The results obtained indicate that with fully hardened steels tempered at $1,200^{\circ} \mathrm{F}$ the presence of relatively small amounts of titanium as introduced into the test steels by the boron addition agents is sufficient to cause an impairment in the Charpy $V$-notch impact properties of the steels or an increased susceptibility to temper brittleness, or both. This was confirmed by the addition of titanium without boron. Similar effects, previously thought possibly due to the presence of zirconium, 
were not observed. The zirconium additions, however, were very small, although within the range of residual amounts usually found in steels treated with addition agents containing zirconium.

The author is indebted to R. J. Leary of the Bureau of Mines, Pittsburgh, Pa., and to R. H.
Harwell of NBS for their invaluable cooperation in melting the experimental steels, and to T. P. Royston and C. R. Irish of NBS for their conscientious assistance during the course of the investigation. The study was sponsored by Wright Air Development Center, with Howard Zoeller acting as project engineer.

Washington, October 26, 1956. 